


\section{EGOTISM IN GERMAN PHILOSOPHY}


All rights reserved 


\section{EGOTISM \\ IN \\ GERMAN PHILOSOPHY}

BY

G. ${ }^{\text {er }}$ SANTAYANA

LATE PROFESSOR OF PHILOSOPHY IN HARVARD UNIVERSITY

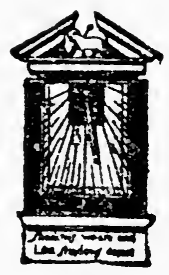

\section{LONDON AND TORONTO}

J. M. DENT E SONS LIMITED NEW YORK : CHARLES SCRIBNER'S SONS 


\section{PREFACE}

Tris book is one of the many that the present war has brought forth, but it is the fruit of a long gestation. During more than twenty years, while I taught philosophy at Harvard College, I had continual occasion to read and discuss German metaphysics. From the beginning it wore in my eyes a rather questionable shape. Under its obscure and fluctuating tenets I felt something sinister at work, something at once hollow and aggressive. It seemed a forced method of speculation, producing more confusion than it found, and calculated chiefly to enable practical materialists to call themselves idealists and rationalists to remain theologians. At the same time the fear that its secret might be eluding me, seeing that by blood and tradition I was perhaps handicapped in the matter, spurred me to great and prolonged efforts to understand what confronted me so bewilderingly. I wished to be as clear and just about it as I could-more clear and just, indeed, than it ever was about itself.

For the rest, German philosophy was never my chief interest, and I write frankly as an outsider, with no professorial pretensions; merely using my common 
reason in the presence of claims put forth by others to a logical authority and a spiritual supremacy which they are far from possessing.

A reader indoctrinated in the German schools is, therefore, free not to read further. My object is neither to repeat his familiar arguments in their usual form, nor to refute them; my object is to describe them intelligibly and to judge them from the point of view of the layman, and in his interests. For those who wish to study German philosophy, the original authors are at hand: all I would give here is the aroma of German philosophy that has reached my nostrils. If the reader has smelt something of the kind, so much the better: we shall then understand each other. The function of history or of criticism is not passively to reproduce its subjectmatter. One real world, with one stout corpus of German philosophy, is enough. Reflection and description are things superadded, things which ought to be more winged and more selective than what they play upon. They are echoes of reality in the sphere of art, sketches which may achieve all the truth appropriate to them without belying their creative limitations: for their essence is to be intellectual symbols, at once indicative and original.

Egotism-subjectivity in thought and wilfulness in morals-which is the soul of German philosophy, 
is by no means a gratuitous thing. It is a genuine expression of the pathetic situation in which any animal finds itself upon earth, and any intelligence in the universe. It is an inevitable and initial circumstance in life. But like every material accident, it is a thing to abstract from and to discount as far as possible. The perversity of the Germans, the childishness and sophistry of their position, lies only in glorifying what is an inevitable impediment, and in marking time on an earthly station from which the spirit of man-at least in spirit-is called to fly.

This glorified and dogged egotism, which a thousand personal and technical evidences had long revealed to me in German philosophy, might now, I should think, be evident to the whole world. Not that the German philosophers are responsible for the war, or for that recrudescence of corporate fanaticism which prepared it from afar. They merely shared and justified prophetically that spirit of uncompromising self-assertion and metaphysical conceit which the German nation is now reducing to action. It is a terrible thing to have a false religion, all the more terrible the deeper its sources are in the human soul. Like many a false religion before it, this which now inspires the Germans has made a double assault upon mankind, one with the secular arm, and another by solemn asseverations and sophistries. This assault, 


\section{EGOTISM IN GERMAN PHILOSOPHY}

though its incidental methods may be dubious, has been bold and honest enough in principle. It has been like those which all conquerors and all founders of militant religions have made at intervals against liberty or reason. And the issue will doubtless be the same. Liberty may be maimed, but not killed; reason may be bent, but not broken. The dark aggression is to be repelled, if possible, by force of arms; but failing that, it will be nullified in time by the indomitable moral resistance which maturer races, richer in wisdom, can exert successfully against the rude will of the conqueror. 


\section{CONTENTS}

CHAP. PAGE

I. The General Character of German Philosophy - II

II. The Protestant Heritage - . . . . 2 I

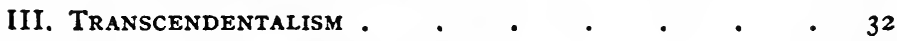

IV. Hints of Egotism in Goethe . . . . . 43

V. SeEds of Egotism IN Kant • . . . . $\quad$ • 54

VI. Transcendentalism Perfected • • . . . 65

VII. Fichte on the Mission of Germany - $\quad$ - 73

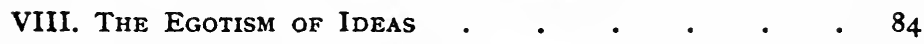

IX. Egotism and Selfishness. • • • • • . 99

X. The Breach with Christianity . . . . . IO4

XI. Nietzsche and Schopenhauer . . . . . II4

XII. The Ethics of Nietzsche. • . • • • $~ I 23$

XIII. The Superman . . • . . . . . • I 36

XIV. HEATHENISM • • • • • • • • • • I44

XV. German Genius - • • • • • • • 154

XVI. Egotism IN Practice • • • • • $\quad$ • 162

INDEX $\quad . \quad+\quad . \quad . \quad . \quad . \quad . \quad 169$ 


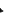




\section{EGOTISM IN GERMAN PHILOSOPHY}

\section{CHAPTER I}

THE GENERAL CHARACTER OF GERMAN PHILOSOPHY

Wнат I propose in these pages to call German philosophy is not identical with philosophy in Germany. The religion of the Germans is foreign to them; and the philosophy associated with religion before the Reformation, and in Catholic circles since, is a system native to the late Roman Empire. Their irreligion is foreign too; the sceptical and the scientific schools that have been conspicuous in other countries have taken root in Germany as well. Thus, if we counted the Catholics and the old-fashioned Protestants on the one hand, and the materialists (who call themselves monists) on the other, we should very likely discover that the majority of intelligent Germans held views which German philosophy proper must entirely despise, and that this philosophy seemed as strange to them as to other people.

For an original and profound philosophy has arisen in Germany, as distinct in genius and method from 


\section{EGOTISM IN GERMAN PHILOSOPHY}

Greek and Catholic philosophy as this is from the Indian systems. The great characteristic of German philosophy is that it is deliberately subjective and limits itself to the articulation of self-consciousness. The whole world appears there, but at a certain remove; it is viewed and accepted merely as an idea framed in consciousness, according to principles fetched from the most personal and subjective parts of the mind, such as duty, will, or the grammar of thought. The direction in which German philosophy is profound is the direction of inwardness. Whatever we may think of its competence in other matters, it probes the self-as unaided introspection may-with extraordinary intentness and sincerity. In inventing the transcendental method, the study of subjective projections and perspectives, it has added a new dimension to human speculation.

The foreign religion and the foreign irreligion of Germany are both incompatible with German philosophy. This philosophy cannot accept any dogmas, for its fundamental conviction is that there are no existing things except imagined ones: God as much as matter is exhausted by the thought of him, and entirely resident in this thought. The notion that knowledge can discover anything, or that anything previously existing can be revealed, is discarded altogether: for there is nothing to discover, and even 


\section{CHARACTER OF GERMAN PHILOSOPHY I3}

if there was, the mind could not reach it; it could only reach the idea it might call up from its own depths. This idea might be perhaps justified and necessary by virtue of its subjective roots in the will or in duty, but never justified by its supposed external object, an object with which nobody could ever compare it. German philosophy is no more able to believe in God than in matter, though it must talk continually of both.

At the same time this subjectivism is not irreligious. It is mystical, faithful, enthusiastic: it has all the qualities that gave early Protestantism its religious force. It is rebellious to external authority, conscious of inward light and of absolute duties. It is full of faith, if by faith we understand not definite beliefs held on inadequate evidence, but a deep trust in instinct and destiny.

Rather than religious, however, this philosophy is romantic. It accepts passionately the aims suggested to it by sentiment or impulse. It despises prudence and flouts the understanding. In Faust and in $P$ ier Gynt we have a poetic echo of its fundamental inspiration, freed from theological accommodations or academic cant. It is the adventure of a wild, sensitive, boyish mind, that now plays the fairy prince and now the shabby and vicious egoist; a rebel and an enthusiast, yet often a sensualist to 


\section{EGOTISM IN GERMAN PHILOSOPHY}

boot by way of experiment; a man eager for experience, but blind to its lessons, vague about nature, and blundering about duty, but confident that he can in some way play the magician and bring the world round to serve his will and spiritual necessities.

Happiness and despair are alike impossible with such a temperament. Its empiricism is perennial. It cannot lose faith in the vital impulse it expresses; all its fancy, ingenuity, and daring philosophy are embroideries which it makes upon a dark experience. It cannot take outer facts very seriously; they are but symbols of its own unfathomable impulses. So pensive animals might reason. The just and humble side of German philosophy-if we can lend it virtues to which it is deeply indifferent-is that it accepts the total relativity of the human mind and luxuriates in it, much as we might expect spiders or porpoises to luxuriate in their special sensibility, making no vain effort to peep through the bars of their psychological prison.

This sort of agnosticism in a minor key is conspicuous in the Critique of Pure Reason. In a major key it reappears in Nietzsche, when he proclaims a preference for illusion over truth. More mystically expressed it pervades the intervening thinkers. The more profound they are the more content and even delighted they are to consider nothing but their own 


\section{CHARACTER OF GERMAN PHILOSOPHY I5}

creations. Their theory of knowledge proclaims that knowledge is impossible. You know only your socalled knowledge, which itself knows nothing; and you are limited to the autobiography of your illusions.

The Germans express this limitation of their philosophy by calling it idealism. In several senses it fully deserves this name. It is idealistic psychologically in that it regards mental life as groundless and allinclusive, and denies that a material world exists, except as an idea necessarily bred in the mind. It is idealistic, too, in that it puts behind experience a background of concepts, and not of matter; a ghostly framework of laws, categories, moral or logical principles to be the stiffening and skeleton of sensible experience, and to lend it some substance and meaning. It is idealistic in morals also, in that it approves of pursuing the direct objects of will, without looking over one's shoulder or reckoning the consequences. These direct objects are ideals, whereas happiness, or any satisfaction based on renunciation and compromise, seems to these spirited philosophers the aim of a degraded, calculating mind. The word idealism, used in this sense, should not mislead us; it indicates sympathy with life and its passions, particularly the learned and political ones; it does not indicate any distaste for material goods or material agencies. The German moral imagination is in its first or dogmatic 


\section{I6 EGOTISM IN GERMAN PHILOSOPHY}

stage, not in the second or critical one. It is in love with life rather than with wisdom.

There is accordingly one sense of the term idealism -the original one-in which this philosophy knows nothing of it, the Platonic and poetic sense in which the ideal is something better than the fact. The Platonic idealist is the man by nature so wedded to perfection that he sees in everything not the reality but the faultless ideal which the reality misses and suggests. Hegel, indeed, drew an outline portrait of things, according to what he thought their ideal essence; but it was uglier and more dreary than the things themselves. Platonic idealism requires a gift of impassioned contemplation, an incandescent fancy that leaps from the things of sense to the goals of beauty and desire. It spurns the earth and believes in heaven, a form of religion most odious to the Germans. They think this sort of idealism not only visionary but somewhat impious; for their own religion takes the form of piety and affection towards everything homely, imperfect, unstable, and progressive. They yearn to pursue the unattainable and encounter the unforeseen. This romantic craving hangs together with their taste for the picturesque and emphatic in the plastic arts, and for the upwelling evanescent emotions of music. Yet their idealism is a religion of the actual. It rejects nothing 
in the daily experience of life, and looks to nothing essentially different beyond. It looks only for more of the same thing, believing in perpetual growth, which is an ambiguous notion. Under the fashionable name of progress what these idealists sincerely cherish is the vital joy of transition; and usually the joy of this transition lies much more in shedding their present state than in attaining a better one. For they suffer and wrestle continually, and by a curious and deeply animal instinct, they hug and sanctify this endless struggle all the more when it rends and bewilders them, bravely declaring it to be absolute, infinite, and divine.

Such in brief is German philosophy, at least, such it might be said to be if any clear account of it did not necessarily falsify it; but one of its chief characteristics, without which it would melt away, is ambiguity. You cannot maintain that the natural world is the product of the human mind without changing the meaning of the word mind and of the word human. You cannot deny that there is a substance without turning into a substance whatever you substitute for it. You cannot identify yourself with God without at once asserting and denying the existence of God and of yourself. When you speak of such a thing as the consciousness of society you must never decide whether you mean the conscious- 


\section{I8 EGOTISM IN GERMAN PHILOSOPHY}

ness individuals have of society or a fabled consciousness which society is to have of itself: the first meaning would spoil your eloquence, and the second would betray your mythology.

What is involved in all these equivocations is not merely a change of vocabulary, that shifting use of language which time brings with it. No, the persistence of the old meanings alone gives point to the assertions that change them and identify them with their opposites. Everywhere, therefore, in these speculations, you must remain in suspense as to what precisely you are talking about. A vague, muffled, dubious thought must carry you along as on a current. Your scepticism must not derange your common sense; your conduct must not express your radical opinions; a certain afflatus must bear you nobly onward through a perpetual incoherence: You must always be thinking not of what you are thinking of but of yourself or of " something higher." Otherwise you cannot live this philosophy or understand it from within.

The mere existence of this system, as of any other, proves that a provocation to frame it is sometimes found in experience or language or the puzzles of reflection. Not that there need be any solidity in it on that account. German philosophy is a sort of religion, and like other religions it may be capable 
of assimilating a great amount of wisdom, while its first foundation is folly. This first folly itself will not lack plausible grounds; there is provocation enough in a single visit to a madhouse for the assertion that the mind can know nothing but the ideas it creates; nevertheless the assertion is false, and such facile scepticism loses sight of the essence of knowledge. The most disparate minds, since they do not regard themselves, may easily regard the same object. Only the maniac stares at his own ideas; he confuses himself in his perceptions; he projects them into the wrong places, and takes surrounding objects to be different from what they are. But perceptions originally have external objects; they express a bodily reaction, or some inward preparation for such a reaction. They are reports. The porpoise and the spider are not shut up in their self-consciousness; however foreign to us may be the language of their senses, they know the sea and air that we know, and have to meet the same changes and accidents there which we meet-and they even have to meet us, sometimes, to their sorrow. Their knowledge does not end in acquaintance with that sensuous language of theirs, whatever it may be, but flies with the import of that language and salutes the forces which confront them in action, and which also confront us. In focussing these forces through the lenses and veils 


\section{EGOTISM IN GERMAN PHILOSOPHY}

of sense knowledge arises; and to arrest our attention on those veils and lenses and say they are all we know, belies the facts of the case and is hardly honest. If we could really do that, we should be retracting the first act of intelligence and becoming artificial idiots. Yet this sophistication is the first principle of German philosophy (borrowed, indeed, from non-Germans), and is the thesis supposed to be proved in Kant's Critique of Pure Reason. 


\section{CHAPTER II}

THE PROTESTANT HERITAGE

THE German people, according to Fichte and Hegel, are called by the plan of Providence to occupy the supreme place in the history of the universe.

A little consideration of this belief will perhaps lead us more surely to the heart of German philosophy than would the usual laborious approach to it through what is called the theory of knowledge. This theory of knowledge is a tangle of equivocations; but even if it were correct it would be something technical, and the technical side of a great philosophy, interesting as it may be in itself, hardly ever determines its essential views. These essential views are derived rather from instincts or traditions which the technique of the system is designed to defend; or, at least, they decide how that technique shall be applied and interpreted.

The moment we hear Fichte and Hegel mentioning a providential plan of the world, we gather that in their view the history of things is not infinite and endlessly various, but has a closed plot like a drama in which one nation (the very one to which these 
philosophers belong) has the central place and the chief rôle: and we perceive at once that theirs is a revealed philosophy. It is the heir of Judaism. It could never have been formed by free observation of life and nature, like the philosophy of Greece or of the Renaissance. It is Protestant theologyrationalised. The element of religious faith, in the Protestant sense of the word faith, is essential to it. About the witness of tradition, even about the witness of the senses, it may be as sceptical as it likes. It may reduce nature and God to figments of the mind; but throughout its criticism of all matters of fact it will remain deeply persuaded that the questioning and striving spirit within is indefeasible and divine. It will never reduce all things, including the mind, to loose and intractable appearances, as might a free idealism. It will employ its scepticism to turn all things into ideas, in order to chain them the more tightly to the moral interests of the thinker. These moral interests, human and pathetic as they may seem to the outsider, it will exalt immeasurably, pronouncing them to be groundless and immutable; and it will never tolerate the suspicion that all things might not minister to them.

From the same tenet of Fichte and Hegel we may also learn that in the plan of the world, as this revealed philosophy conceives it, the principal figures 
are not individuals, like the Creator, the Redeemer, and one's own soul, but nations and institutions. It is of the essence of Protestantism and of German philosophy that religion should gradually drop its supernatural personages and comforting private hopes and be absorbed in the duty of living manfully and conscientiously the conventional life of this world. Not the whole life of the world, however, since gay religions and many other gay things are excluded, or admitted only as childish toys. Positive religion, in fact, disappears, as well as the frivolous sort of worldliness, and there remains only a consecrated worldliness that is deliberate and imposed as a duty. Just as in pantheism God is naturalised into a cosmic force, so in German philosophy the Biblical piety of the earlier Protestants is secularised into social and patriotic zeal.

German philosophy has inherited from Protestantism its earnestness and pious intention; also a tendency to retain, for whatever changed views it may put forward, the names of former beliefs. God, freedom, and immortality, for instance, may eventually be transformed into their opposites, since the oracle of faith is internal; but their names may be kept, together with a feeling that what will now bear those names is much more satisfying than what they originally stood for. If it should seem that 


\section{EGOTISM IN GERMAN PHILOSOPHY}

God came nearest to us, and dwelt within us, in the form of vital energy, if freedom should turn out really to mean personality, if immortality, in the end, should prove identical with the endlessness of human progress, and if these new thoughts should satisfy and encourage us as the evanescent ideas of God, freedom, and immortality satisfied and encouraged our fathers, why should we not use these consecrated names for our new conceptions, and thus indicate the continuity of religion amid the flux of science? This expedient is not always hypocritical. It was quite candid in men like Spinoza and Emerson, whose attachment to positive religion had insensibly given way to a half-mystical, half-intellectual satisfaction. with the natural world, as their eloquent imagination. conceived it. But whether candid or disingenuous, this habit has the advantage of oiling the wheels of progress with a sacred unction. In facilitating change it blurs the consciousness of change, and leads people to associate with their new opinions sentiments which are logically incompatible with them. The attachment of many tender-minded people to German philosophy is due to this circumstance, for German philosophy is not tender.

The beauty and the torment of Protestantism is that it opens the door so wide to what lies beyond it. This progressive quality it has fully transmitted 
to all the systems of German philosophy. Not that each of them, like the earlier Protestant sects, does not think itself true and final; but in spite of itself it suggests some next thing. We must expect, therefore, that the more conservative elements in each system should provoke protests in the next generation; and it is hard to say whether such inconstancy is a weakness, or is simply loyalty to the principle of progress. Kant was a puritan; he revered the rule of right as something immutable and holy, perhaps never obeyed in the world. Fichte was somewhat freer in his Calvinism; the rule of right was the moving power in all life and nature, though it might have been betrayed by a doomed and selfseeking generation. Hegel was a very free and superior Lutheran; he saw that the divine will was necessarily and continuously realised in this world, though we might not recognise the fact in our petty moral judgments. Schopenhauer, speaking again for this human judgment, revolted against that cruel optimism, and was an indignant atheist; and finally, in Nietzsche, this atheism became exultant; he thought it the part of a man to abet the movement of things, however calamitous, in order to appropriate its wild force and be for a moment the very crest of its wave.

Protestantism was not a reformation by accident, 


\section{EGOTISM IN GERMAN PHILOSOPHY}

because it happened to find the church corrupt; it is a reformation essentially, in that every individual must reinterpret the Bible and the practices of the church in his own spirit. If he accepted them without renewing them in the light of his personal religious experience, he would never have what Protestantism thinks living religion. German philosophy has inherited this characteristic; it is not a cumulative science that can be transmitted ready made. It is essentially a reform, a revision of traditional knowledge, which each neophyte must make for himself, under pain of rendering only lip-service to transcendental truth, and remaining at heart unregenerate. His chief business is to be converted; he must refute for himself the natural views with which he and all other men have begun life. And still these viewslike the temptations of Satan-inevitably form themselves afresh in each generation, and even in the philosopher, between one spell of introspective thought and another, so that he always has to recapitulate his saving arguments from the beginning. Each new idealist in each of his books, often in every lecture and every chapter, must run back to refute again the same homely opponents-materialism, naturalism, dualism, or whatever he may call them. Dead as each day he declares these foes to be, he has to fight them again in his own soul on the morrow. 
Hence his continual preoccupation lest he fall away, or lest the world should forget him. To preserve his freedom and his idealism he must daily conquer them anew. This philosophy is secondary, critical, sophistical; it has a perennial quarrel with inevitable opinions.

Protestantism, in spite of its personal status, wished to revert to primitive Christianity.. In this desire it was guided partly by a conventional faith in the Scriptures, and partly by a deep sympathy with experimental religion. German religion and philosophy are homesick: they wish to be quite primitive once more. And they actually remain primitive in spirit, spontaneous and tentative, even in the midst of the most cumbrous erudition, as a composition of Dürer's, where flesh, fish, and fowl crowd every corner, still remains primitive, puzzled, and oppressed. Such a naive but overloaded mind is lost in admiration of its own depth and richness; yet, in fact, it is rather helpless and immature; it has not learned to select what suffices, or to be satisfied with what is best.

Faith for the Germans must be a primitive and groundless assurance, not knowledge credibly transmitted by others whose experience may have been greater than our own. Even philosophy is not conceived as a reasonable adjustment to what may have 


\section{EGOTISM IN GERMAN PHILOSOPHY}

been discovered to be the constitution of the world; it is in the first instance a criticism, to dissolve that reputed knowledge, and then, when primitive innocence is happily restored, it is a wager or demand made beyond all evidence, and in contempt of all evidence, in obedience to an innate impulse. Of course, it is usual, as a concession to the weaker brethren, to assume that experience, in the end, will seem to satisfy these demands, and that we shall win our bets and our wars; but the point of principle, borrowed by German philosophy from Protestantism, is that the authority of faith is intrinsic and absolute, while any external corroboration of it is problematical and not essential to the rightness of the assumptions that faith makes. In this we have a fundamental characteristic of the school. Carried (as it seldom is) to its logical conclusion, it leads to the ultra-romantic and ultra-idealistic doctrine that the very notion of truth or fact is a fiction of the will, invented to satisfy our desire for some fixed point of reference in thought. In this doctrine we may see the culmination of the Protestant rebellion against mediation in religion, against external authority, and against dogma.

The Protestant precept to search the Scriptures, and the sense that every man must settle the highest questions for himself, have contributed to the zeal 
with which science and scholarship have been pursued in Germany. In no other country has so large, so industrious, and (amid its rude polemics) so cooperative a set of professors devoted itself to all sorts of learning. But as the original motive was to save one's soul, an apologetic and scholastic manner has often survived: the issue is prejudged and egotism has appeared even in science. For favourable as Protestantism is to investigation and learning, it is almost incompatible with clearness of thought and fundamental freedom of attitude. If the controlling purpose is not political or religious, it is at least " philosophical," that is to say, arbitrary.

We must remember that the greater part of the "facts" on which theories are based are reported or inferred facts-all in the historical sciences, since the documents and sources must first be pronounced genuine or spurious by the philosophical critic. Here presumptions and private methods of inference determine what shall be admitted for a fact, to say nothing of the interpretation to be given to it. Hence a piece of Biblical or Homeric criticism, a history of Rome or of Germany often becomes a little system of egotistical philosophy, posited and defended with all the parental zeal and all the increasing conviction with which a prophet defends his supernatural inspirations. 


\section{EGOTISM IN GERMAN PHILOSOPHY}

The distinction between Mary and Martha is not a German distinction: in Germany the rapt idealist is busy about many things, so that his action is apt to be heady and his contemplation perturbed. Only the principle is expected to be spiritual, the illustrations must all be material and mundane. There is no paradox in German idealism turning to material science, commerce, and war for a fresh field of operation. No degeneracy is implied in such an extension of its vocation, especially when the other ideals of the state-pure learning, art, social organisationare pursued at the same time with an equal ardour. The test of a genuine German idealist is that he should forget and sink his private happiness in whatever service the state may set him to do.

In view of this political fidelity the changing opinions of men are all indifferent to true religion. It is not a question of correctness in opinion or conduct, since for the idealist there can be no external standard of truth, existence, or excellence on which such correctness could depend. Ideas are so much real experience and have no further subjectmatter. Thought is simply more or less rich, elaborate, or vehement, like a musical composition, and more or less consistent with itself. It is all a question of depth and fulness of experience, obtained by hacking one's way through this visionary and bewitched 
existence, the secret purpose of which is to serve the self in its development. In this philosophy imagination that is sustained is called knowledge, illusion that is coherent is called truth, and will that is systematic is called virtue.

Evidently the only sanction or vindication that such a belief will look for is the determination to reassert it. Religion is here its own heaven, and faith the only proof of its own truth. What is harmonised in the end is not the experience through which people have actually passed but only the echoes of that experience chiming in the mystic ear. Memory too can play the egotist. Subjectivism can rule even within the subject and can make him substitute his idea of himself, in his most self-satisfied moment, for the poor desultory self that he has actually been.

The German philosophers have carried on Protestantism beyond itself. They have separated the two ingredients mingled in traditional religions. One of these ingredients-the vital faith or self-trust of the animal will-they have retained. The other-the lessons of experience-they have rejected. To which element the name of religion should still be given, if it is given to either, is a matter of indifference. The important thing is that, call it religion or irreligion, we should know what we are clinging to. 


\section{CHAPTER III}

\section{TRANSCENDENTALISM}

Fichte called Locke the worst of philosophers, but it was ungrateful of him, seeing that his own philosophy was founded on one of Locke's errors. It was Locke who first thought of looking into his own breast to find there the genuine properties of gold and of an apple; and it is clear that nothing but lack of consecutiveness and courage kept him from finding the whole universe in the same generous receptacle. This method of looking for reality in one's own breast, when practised with due consecutiveness and courage by the Germans, became the transcendental method; but it must be admitted that the German breast was no longer that anatomical region which Locke had intended to probe, but a purely metaphysical point of departure, a migratory ego that could be here, there, and everywhere at once, being present at any point from which thought or volition might be taken to radiate. It was no longer so easy to entrap as the soul of Locke, which he asserted travelled with him in his coach from London to Oxford. But the practice of 
looking for all things within one's own breast, in the subtler sense of searching for them in one's memory and experience, begat in time the whole romantic and subjective school of philosophy.

Leibniz, the first of German philosophers, although an enemy of Locke's sensualism and of his slackness in logic, was even more explicit in assigning a mental seat to all sensible objects. The soul, he said, had no windows and, he might have added, no doors; no light could come to it from without; and it could not exert any transitive force or make any difference beyond its own insulated chamber. It was a camera obscura, with a universe painted on its impenetrable walls. The changes which went on in it were like those in a dream, due to the charge of pent-up energies and fecundities within it; for the Creator had wound it up at the creation like a clock, destined to go for ever, striking infinite hours, with ever richer chimes.

Here, in miniature, with a clearness and beauty never afterwards equalled, we have the nature and movement of the transcendental self set forth before us: a closed circle of experience, admitting of no relations with anything beyond, but infinite in its own potential developments, and guided by an inner force, according to an innate unconscious plan. All duties, all principles of interpretation, all data, all 


\section{EGOTISM IN GERMAN PHILOSOPHY}

visioned objects, operated within this single life, diversifying its field of view, and testifying to its secret endowment.

Nevertheless, the later idealists, ungrateful to Locke for their first principle, were ungrateful also to Leibniz for their ultimate conception, anticipated by him in all its completeness. There were reasons, of course, for this ingratitude. Leibniz, like the transcendentalists, had supposed that the objects of sense, as experience reveals them, were begotten out of the latent nature of the soul; but he had also conceived that there were many souls, as many as atoms in the physical world, and that the images arising in each were signs of the presence and actual condition of its companions. Thus perception, while yielding directly only an idea, as in a dream, wás indirectly symbolic of an outer reality, like a dream significant and capable of interpretation. And being an undaunted rationalist, Leibniz assumed that the soothsayer capable of reading this dream was reason, and that whatever reason conceived to be right and necessary actually must be true in the great outer world.

It was at this point that Kant deviated into his radical subjectification of knowledge. His mind had been more open than that of Leibniz to the influences of English psychology, it had stewed longer in its 
own juice, and he could not help asking how, if the senses could reveal only ideas of sense, reason was ever able to reveal anything but ideas of reason. Those inferences about the vast world outside, which Leibniz had allowed his spirits to make in their solitary confinement, were reduced by the more scrupulous Kant to scribblings upon their prison walls. These scribblings he officially termed the ideas of pure-that is, of unsupported-reason; but in his private capacity he gently continued to agree with Leibniz and to believe them true.

There was no anomaly, according to Kant, in this situation. An idea might by chance be the image of a reality, but we could never know that it was. For the proof would have to be supplied by a further idea, and would terminate in that. The hypothesis and the corroboration would alike be mental, since experience was of ideas and could envisage nothing but the vicissitudes of the mind.

If you had asked Leibniz what determined the order in which perceptions came into any mind, he would doubtless have answered that the Creator did so, or (translating that symbol into its analytic equivalent in his system) that what did so was the innate destiny or predisposition of that mind to develop in harmony with the best possible universe. Here is a very remarkable unconscious principle of 


\section{EGOTISM IN GERMAN PHILOSOPHY}

evolution seated in the spirit and presiding over all its experience. This is precisely what is meant by a transcendental principle.

This principle, unconscious as it is, sometimes betrays its mighty workings to consciousness. Besides the incidental multitude of ideas which it breeds, it makes itself felt in subterranean strains and rumblings, in the sense of movement and of longing. This darker but deeper manifestation of the transcendental clockwork Leibniz called appetition, and under the name of Will it has played a great part in later German systems. To call it Will is, of course, to speak improperly and mythologically, for actual willing requires an idea of what is willed. When we say a man doesn't know what he wants, we mean that he can will nothing, for lack of a clear idea of his interests and situation, although he doubtless wants or lacks many specific things, the absence of which is rendering him unhappy and restless. These instinctive appetitions for objects of which the mind is ignorant may, by a figure of speech, be called unconscious Will; a phrase which would be a contradiction in terms if this word Will (which I write with a capital letter) were not used metaphorically. From this metaphor, when its boldness seems to be dulled by use, we may pass insensibly to giving the name of Will to that whole transcendental potency 
of the soul which, like the mainspring of a watch; lay coiled up tightly within it from the beginning of time. A man's transcendental Will can then be called the source of everything that ever happens to him his birth, his character, his whole life, and his death -all that he most detests and most emphatically does not will, like his nightmares, being an expression of the original pregnancy of his spirit, and its transcendental principle of development.

There is but one thing to add touching a point often left by these philosophers in the most hopeless obscurity. In Leibniz the number of spirits was infinite: in the later systems they are reduced to one. This difference seems greater than it is, for when such terms as Spirit or Will are used metaphorically, standing for unconscious laws of continuity or development, and when the Will or Spirit present in me now may be said to have presided over the destinies of my soul infinite ages before I was born, there seems to be no good reason why the same Spirit or Will should not preside over all the inhabitants of the universe at all times, be they gods or humming-birds. Such a Spirit or Will resembles the notion of Providence, or the law of evolution, or the pre-established harmony of Leibniz far more than it resembles a mind. Those philosophers, intent on proving that the Spirit can be only one, might 


\section{EGOTISM IN GERMAN PHILOSOPHY}

have proceeded, therefore, by urging that a Spirit was at best a formal and abstract law, covering such disparate facts, that all flesh and fowl, all demons and angels, might just as well be animated by a single Spirit. As it takes all sorts of things to make a world, it might take all sorts of things to express a Spirit.

This cool and consciously verbal way of making all one, however, is not the way of the Germans. No doubt in practice the unity of the Spirit or Will in their systems amounts to nothing more, yet their intention and illusion is rather that whenever two things can be called manifestations of one Spirit in the loosest and most metaphorical sense of this word they are thereby proved to be data in one spirit in the most intimate and psychological sense of the same. So that what really happens to transcendentalists is not that they unite all the transcendental units of Leibniz into one even looser transcendental unit, but that they limit the universe to what in Leibniz was one of an infinite number of parallel careers. Nay, they limit even that one career to the experience present at one point, that of the most intense and comprehensive self-consciousness.

The unity they desire and believe in is accordingly an actual and intense unity. All its elements are to be viewed at once, bound and merged together by 
the simultaneous intuition of all their relations, and this in a single, unchanging, eternal moment of thought, or rather of unutterable feeling. The union is, therefore, real, psychic, mystical, and so close that everything that was to be united there, by a curious irony, remains outside.

What can lead serious thinkers, we may ask, into such pitfalls and shams? In this case, a powerful and not unworthy motive. All transcendentalism takes the point of view of what it calls knowledge; whenever it mentions anything-matter, God, oneself -it means not that thing but the idea of it. By knowledge it understands the image or belief, the fact of cognition. Whatever is thought of exists, or can exist, in this philosophy, only for thought; yet this thought is called not illusion but knowledge, because knowledge is what the thought feels that it is.

Evidently on this principle none of Leibniz's spirits could know any other, nor could any phase of the same spirit know any other phase. The unbridgeable chasm of want of experience would cut off knowledge from everything but its "content," the ideas it has of its objects. Those fabled external objects would be brought back into my ideas, and identified with them; my ideas in turn would be drawn in and identified with the fact that I entertain them and this fact itself would condense into the 


\section{EGOTISM IN GERMAN PHILOSOPHY}

more intimate and present fact that intensely, vaguely, deeply I feel that I am, or am tending to be, something or other. My Will or Spirit, the rumble of my unconscious appetitions, thus absorbs my ideas, my ideas absorb their objects, and these objects absorb the world, past, present, and future. Earth and heaven, God and my fellowmen are mere expressions of my Will, and if they were anything more, I could not now be alive to their presence. My Will is absolute. With that conclusion transcendentalism is complete.

Is such transcendentalism impossibly sceptical? Is it absurdly arrogant? Is it wonderfully true?

In so complex a world as this, there is room for a great number of cross-vistas: when all has been surveyed from one point of view and in one set of terms, nothing excludes the same reality from being surveyed from a different centre and expressed in a different notation. To represent a man, sculpture is apparently exhaustive; yet it does not exclude painting, or the utterly disparate description of the man in words; surveys in which there need be no contradiction in the deliverance, though there is the widest diversity and even incommensurability in the methods. Each sort of net drawn through the same sea catches a different sort of fish; and the fishermen may quarrel about what the sea contained, if each regards his draught as exhaustive. Yet the sea con- 
tained all their catches, and also the residue, perhaps infinite, that escaped them all.

Now one net which every intelligent being casts over things is that of his own apprehension, experience, and interests. He may not reflect often on his personal principle of selection and arrangement; he may be so interested in the movements he sees through his glass as never to notice the curious circular frame, perhaps prismatic, which his glass imposes on the landscape. Yet among all the properties of things, the adventitious properties imputed to them in apprehension are worth noting too; indeed, it chastens and transforms our whole life if we have once noted them and taken them to heart. Not that this circumstance implies for a moment what the dizziness of idealists has inferred, that things exist only as perceived or when we perceive them. What follows is rather that, besides the things and in the most interesting contrast to their movement, there is the movement of our minds in observing them. If, for instance, I happen not to know the name of my great-grandfather, and am vexed at my ignorance, I may search the parish records and discover it, together with many circumstances of his life. This does not prove that my interest in genealogy created my great-grandfather, as a consistent egotist would assert; but it does show how my interest was a 


\section{EGOTISM IN GERMAN PHILOSOPHY}

nucleus for my discoveries and for the terms, such as great-grandfather, in which I express them-for it was no intrinsic property of that worthy man that he was to become my great-grandfather after his death, or that I was to discover him.

This vortex which things, as apprehension catches them, seem to form round each whirling spectator, is the fascinating theme of lyric poetry, of psychological novels, and of German philosophy. Dominated as this philosophy is by the transcendental method, it regards views, and the history and logic of views, as more primitive and important than the objects which these views have in common. The genial Professor Paulsen of Berlin (whose pupil I once had the advantage of being) had a phrase that continually recurred in his lectures: Man kann sagen, as much as to say, Things will yield the following picture, if one cares to draw it. And he once wrote an article in honour of Kant very pertinently entitled: $W$ as uns Kant sein kann; because no veritable disciple of Kant accepts what Kant taught as he taught it, but each rises from the study of the master having irresistibly formed one or more systems of his own. To take what views we will of things, if things will barely suffer us to take them, and then to declare that the things are mere terms in the views we take of them-that is transcendentalism. 


\section{CHAPTER IV}

\section{HINTS OF EGOTISM IN GOETHE}

All transcendentalists are preoccupied with the self, but not all are egotists. Some regard as a sad disability this limitation of their knowledge to what they have created; they are humble, and almost ashamed to be human, and to possess a mind that must cut them off hopelessly from all reality. On the other hand there are many instinctive egotists who are not transcendentalists, either because their attention has not been called to this system, or because they discredit all speculation, or because they see clearly that the senses and the intellect, far from cutting us off from the real things that surround us, have the function of adjusting our action to them and informing our mind about them. Such an instinctive egotist does not allege that he creates the world by willing and thinking it, yet he is more interested in his own sensations, fancies, and preferences than in the other things in the world. The attention he bestows on things seems to him to bathe in light their truly interesting side. What he chiefly considers is his own experience - what he 


\section{EGOTISM IN GERMAN PHILOSOPHY}

cared for first, what second, what he thinks to-day, what he will probably think to-morrow, what friends he has had, and how they have lost their charm, what religions he has believed in, and in general what contributions the universe has made to him and he to the universe. His interest in personality need not be confined to his own; he may have a dramatic imagination, and may assign their appropriate personality to all other people; every situation he hears of or invents may prompt him to conceive the thrilling passions and pungent thoughts of some alter ego, in whom latent sides of his own nature may be richly expressed. And impersonal things, too, may fascinate him, when he feels that they stir his genius fruitfully; and he will be the more ready to scatter his favours broadcast in that what concerns him is not any particular truth or person (things which might prove jealous and exclusive), but rather the exercise of his own powers of universal sympathy.

Something of this sort seems to appear in Goethe; and although his contact with philosophical egotism was but slight, and some of his wise maxims are incompatible with it, yet his romanticism, his feeling for development in everything, his private life, the nebulous character of his religion, and some of his most important works, like Faust and Wilbelm Meister, are all so full of the spirit of German 
philosophy, that it would be a pity not to draw some illustration for our subject from so pleasant a source.

There are hints of egotism in Goethe, but in Goethe there are hints of everything, and it would be easy to gather an imposing mass of evidence to the effect that he was not like the transcendentalists, but far superior to them. For one thing he was many-sided, not encyclopædic; he went out to greet the variety of things, he did not pack it together. He did not even arrange the phases of his experience (as he did those of Faust) in an order supposed to be a progress, although, as the commentators on Faust inform us, not a progress in mere goodness. Hegel might have understood all these moral attitudes, and described them in a way not meant to appear satirical; but he would have criticised and demolished them, and declared them obsolete-all but the one at which he happened to stop. Goethe loved them all; he hated to outgrow them, and if involuntarily he did so, at least he still honoured the feelings that he had lost. He kept his old age genial and green by that perennial love. In order to hold his head above water and be at peace in his own heart, he did not need to be a Christian, a pagan, or an epicurean; yet he lent himself unreservedly, in imagination, to Christianity, paganism, and sensuality-three things 


\section{EGOTISM IN GERMAN PHILOSOPHY}

your transcendental egotist can never stomach: each in its way would impugn his self-sufficiency.

Nevertheless the sympathies of Goethe were only romantic or æsthetic; they were based on finding in others an interesting variation from himself, an exotic possibility, rather than an identity with himself in thought or in fate. Christianity was an atmosphere necessary to certain figures, that of Gretchen, for instance, who would have been frankly vulgar without it; paganism was a learned masque, in which one could be at once distinguished and emancipated; and sensuality was a sentimental and scientific licence in which the free mind might indulge in due season. The sympathy Goethe felt with things was that of a lordly observer, a traveller, a connoisseur, a philanderer; it was egotistical sympathy.

Nothing, for instance, was more romantic in Goethe than his classicism. His Ipbigenie and his Helena and his whole view of antiquity were full of the pathos of distance. That pompous sweetness, that intense moderation, that moral somnambulism were too intentional; and Goethe felt it himself. In Faust, after Helen has evaporated, he makes the hero revisit his native mountains and revert to the thought of Gretchen. It is a wise home-coming, because that craze for classicism which Helen symbolised alienated the mind from real life and led 
only to hopeless imitations and lackadaisical poses. Gretchen's garden, even the Walpurgisnacht, was in truth more classical. This is only another way of saying that in the attempt to be Greek the truly classical was missed even by Goethe, since the truly classical is not foreign to anybody. It is precisely that part of tradition and art which does not alienate us from our own life or from nature, but reveals them in all their depth and nakedness, freed from the fashions and hypocrisies of time and place. The effort to reproduce the peculiarities of antiquity is a proof that we are not its natural heirs, that we do not continue antiquity instinctively. People can mimic only what they have not absorbed. They reconstruct and turn into an archæological masquerade only what strikes them as outlandish. The genuine inheritors of a religion or an art never dream of reviving it; its antique accidents do not interest them, and its eternal substance they possess by nature.

The Germans are not in this position in regard to the ancients. Whether sympathetic like Goethe, or disparaging like Burckhardt, or both at once, like Hegel, they have seen in antiquity its local colour, its mannerisms, its documents, and above all its contrasts with the present. It was not so while the traditions of antiquity were still living and authori- 


\section{EGOTISM IN GERMAN PHILOSOPHY}

tative. But the moderns, and especially the Germans, have not a humble mind. They do not go to school with the Greeks unfeignedly, as if Greek wisdom might possibly be true wisdom, a pure expression of experience and reason, valid essentially for us. They prefer to take that wisdom for a phase of sentiment, of course outgrown, but still enabling them to reconstruct learnedly the image of a fascinating past. This is what they call giving vitality to classical studies, turning them into Kulturgescbichte. This is a vitality lent by the living to the dead, not one drawn by the young and immature from a perennial fountain. In truth classical studies were vital only so long as they were still authoritative morally and set the standard for letters and life. They became otiose and pedantic when they began to serve merely to recover a dead past in its trivial detail, and to make us grow sentimental over its remoteness, its beauty, and its ruins.

How much freer and surer was Goethe's hand when it touched the cord of romanticism! How perfectly he knew the heart of the romantic egotist! The romantic egotist sets no particular limits to the range of his interests and sympathies; his programme, indeed, is to absorb the whole world. $\mathrm{He}$ is no wounded and disappointed creature, like Byron, that takes to sulking and naughtiness because things 
taste bitter in his mouth. He finds good and evil equally digestible. The personal egotism of Byron or of Musset after all was humble; it knew how weak it was in the universe. But absolute egotism in Goethe, as in Emerson, summoned all nature to minister to the self: all nature, if not actually compelled to this service by a human creative fiat, could at least be won over to it by the engaging heroism of her favourite child. In his warm pantheistic way Goethe felt the swarming universal life about him; he had no thought of dragooning it all, as sectarians and nationalists would, into vindicating some particular creed or nation. Yet that fertile and impartial universe left each life free and in uncensored competition with every other life. Each creature might feed blamelessly on all the others and become, if it could, the focus and epitome of the world. The development of self was the only duty, if only the self was developed widely and securely enough, with insight, calmness, and godlike irresponsibility.

Goethe exhibited this principle in practice more plainly, perhaps, than in theory. His family, his friends, his feelings were so many stepping-stones in his moral career; he expanded as he left them behind. His love-affairs were means to the fuller realisation of himself. Not that his love-affairs were sensual or his infidelities callous; far from it. They 


\section{EGOTISM IN GERMAN PHILOSOPHY}

often stirred him deeply and unsealed the springs of poetry in his heart; that was precisely their function. Every tender passion opened before him a primrose path into which his inexorable genius led him to wander. If in passing he must tread down some flower, that was a great sorrow to him; but perhaps that very sorrow and his inevitable remorse were the most needful and precious elements in the experience. Every pathetic sweetheart in turn was a sort of Belgium to him; he violated her neutrality with a sigh; his heart bled for her innocent sufferings, and he never said afterwards in selfdefence, like the German Chancellor, that she was

1. no better than she should be. But he must press on. His beckoning destiny, the claims of his spiritual growth, compelled him to sacrifice her and to sacrifice his own lacerated feelings on the altar of duty to his infinite self. Indeed, so truly supreme was this vocation that universal nature too, he thought, was bound to do herself some violence in his behalf and to grant him an immortal life, that so noble a process of self-expansion might go on for ever.

Goethe's perfect insight into the ways of romantic egotism appears also in Faust, and not least in the latter parts of it, which are curiously prophetic. If the hero of that poem has a somewhat incoherent character, soft, wayward, emotional, yet at the same 
time stubborn and indomitable, that circumstance only renders him the fitter vehicle for absolute Will, a metaphysical entity whose business is to be vigorous and endlessly energetic while remaining perfectly plastic. Faust was at first a scholar, fervid and grubbing, but so confused and impatient that he gave up science for magic. Notwithstanding the shams of professional people which offended him, a private and candid science was possible, which might have brought him intellectual satisfaction; and the fact would not have escaped him if he had been a simple lover of truth. But absolute Will cannot be restricted to any single interest, much less to the pursuit of a frigid truth in which it cannot believe; for the Will would not be absolute if it recognised any truth which it had to discover; it can recognise and love only the truth that it makes. Its method of procedure, we are told, consists in first throwing out certain assumptions, such perhaps as that everything must have a cause or that life and progress must be everlasting; and the truth is then whatever conforms to these assumptions. But since evidently these assumptions might be utterly false, it is clear that what interests absolute Will is not truth at all, but only orthodoxy. A delightful illustration of this is given by Faust when, emulating Luther for a moment, he undertakes to translate the 
52 EGOTISM IN GERMAN PHILOSOPHY

first verse of Saint John-that being the Gospel that impresses him most favourably. The point is not prosaically to discover what the Evangelist meant; but rather what he must and shall have meant. The Word will never do; the Sense would be somewhat better; but In the beginning was Force would have even more to recommend it. Suddenly, however, what absolute Will demands flashes upon him, and he writes down contentedly: In the beginning was the Deed:

\section{Auf einmal seh' ich Rat}

Und schreibe getrost: Im Anfang war die That!

Yet even in this exciting form, the life of thought cannot hold him long. He aches to escape from it; not that his knowledge of the sciences, as well as his magic, will not accompany him through life; he will not lose his acquired art nor his habit of reflection, and in this sense his career is really a progress, in that his experience accumulates; but the living interest is always something new. He turns to miscellaneous adventures, not excluding love; from that he passes to imperial politics, a sad mess, thence to sentimental classicism, rather an unreality, and finally to war, to public works, to trade, to piracy, to colonisation, and to clearing his acquired estates of tiresome old natives, who insist on ringing church bells and are impervious to the new Kultur. These public 
enterprises he finds more satisfying, perhaps only because he dies in the midst of them.

Are these hints of romantic egotism in Goethe mere echoes of his youth and of the ambient philosophy, echoes which he would have rejected if confronted with them in an abstract and doctrinal form, as he rejected the system of Fichte? Would he not have judged Schopenhauer more kindly? Above all, what would he have thought of Nietzsche, his own wild disciple? No doubt he would have wished to buttress and qualify in a thousand ways that faith in absolute Will which they emphasised so exclusively, Schopenhauer in metaphysics and Nietzsche in morals. But the same faith was a deep element in his own genius, as in that of his country, and he would hardly have disowned it. 


\section{CHAPTER V}

SEEDS OF EGOTISM IN KANT

KANT is remarkable among sincere philosophers for the pathetic separation which existed between his personal beliefs and his official discoveries. His personal beliefs were mild and half orthodox and hardly differed from those of Leibniz; but officially he was entangled in the subjective criticism of knowledge, and found that the process of knowing was so complicated and so exquisitely contrived to make knowledge impossible, that while the facts of the universe were there, and we might have, like Leibniz, a shrewd and exact notion of what they were, officially we had no right to call them facts or to allege that we knew them. As there was much in Kant's personal belief which this critical method of his could not sanction, so there were implications and consequences latent in his critical method which he never absorbed, being an old man when he adopted it. One of these latent implications was egotism.

The fact that each spirit was confined to its own perceptions condemned it to an initial subjectivity and agnosticism. What things might exist besides his ideas he could never know. That such things 
existed was not doubted; Kant never accepted that amazing principle of dogmatic egotism that nothing is able to exist unless I am able to know it. On the contrary he assumed that human perceptions, with the moral postulates which he added to them, were symbols of a real world of forces or spirits existing beyond. This assumption reduced our initial idiotism to a constitutional taint of our animal minds, not unlike original sin, and excluded that romantic pride and self-sufficiency in which a full-fledged transcendentalism always abounds.

To this contrite attitude of Kant's agnosticism his personal character and ethics corresponded. A wizened little old bachelor, a sedentary provincial scribe, scrupulous and punctual, a courteous moralist who would have us treat humanity in the person of another as an end and never merely as a means, a pacifist and humanitarian who so revered the moral sense according to Shaftesbury and Adam Smith that, after having abolished earth and heaven, he was entirely comforted by the sublime truth that nevertheless it remained wrong to tell a lie-such a figure has nothing in it of the officious egotist or the superman. Yet his very love of exactitude and his scruples about knowledge, misled by the psychological fallacy that nothing can be an object of knowledge except some idea in the mind, led him 


\section{EGOTISM IN GERMAN PHILOSOPHY}

in the end to subjectivism; while his rigid conscience, left standing in that unnatural void, led him to attribute absoluteness to what he called the categorical imperative. But this void outside and this absolute oracle within are germs of egotism, and germs of the most virulent species.

The categorical imperative, or unmistakable voice of conscience, was originally something external enough-too external, indeed, to impose by itself a moral obligation. The thunders of Sinai and the voice from the whirlwind in Job fetched their authority from the suggestion of power; there spoke an overwhelming physical force of which we were the creatures and the playthings, a voice which far. from interpreting our sense of justice, or our deepest hopes, threatened to crush and to flout them. If some of its commandments were moral, others were ritual or even barbarous; the only moral sanction. common to them all came from our natural prudence and love of life; our wisdom imposed on us the fear of the Lord. The prophets and the gospel did much to identify this external divine authority with the human conscience; an identification which required a very elaborate theory of sin and punishment and of existence in other worlds, since the actual procedure of nature and history can never be squared with any ideal of right. 
In Kant, who in this matter followed Calvin, the independence between the movement of nature, both within and without the soul, and the ideal of right was exaggerated into an opposition. The categorical imperative was always authoritative, but perhaps never obeyed. The divine law was far from being. like the absolute Will in Fichte, Hegel, and Schopenhaver, a name for a universal metaphysical force, or even for the flux of material substance. On the contrary the sublimity of the categorical imperative lay precisely in the fact that, while matter and life moved on in their own unregenerate way, a principle which they ought to follow, overarched and condemned them, and constrained them to condemn themselves. Human nature was totally depraved and incapable of the least merit, nor had it any power of itself to become righteous. Its amiable spontaneous virtues, having but a natural motive, were splendid vices. Moral worth began only when the will, transformed at the touch of unmerited grace, surrendered every impulse in overwhelming reverence for the divine law.

This Calvinistic doctrine might seem to rebuke all actual inclinations, and far from making the will morally absolute, as egotism would, to raise over against it an alien authority, what ought to be willed. Such was, of course, Kant's ostensible intention; but 


\section{EGOTISM IN GERMAN PHILOSOPHY}

sublime as such a situation was declared to be, he felt rather dissatisfied in its presence. A categorical imperative crying in the wilderness, a duty which nobody need listen to, or suffer for disregarding, seemed rather a forlorn authority. To save the face of absolute right another world seemed to be required, as in orthodox Christianity, in which it might be duly vindicated and obeyed.

Kant's scepticism, by which all knowledge of reality was denied us, played conveniently into the hands of this pious requirement. If the whole natural world, which we can learn something about by experience, is merely an idea in our minds, nothing prevents any sort of real but unknown world from lying about us unawares. What could be more plausible and opportune than that the categorical imperative which the human mind, the builder of this visible world, had rejected, should in that other real world be the head stone of the corner?

This happy thought, had it stood alone, might have seemed a little fantastic; but it was only a laboured means of re-establishing the theology of Leibniz, in which Kant privately believed, behind the transcendental idealism which he had put forward professorially. The dogmatic system from which he started seemed to him, as it stood, largely indefensible and a little oppressive. To purify it he 
adopted a fallacious principle of criticism, namely, that our ideas are all we can know, a principle which, if carried out, would undermine that whole system, and every other. $\mathrm{He}$, therefore, hastened to adopt a corrective principle of reconstruction, no less fallacious, namely, that conscience bids us assume certain things to be realities which reason and experience know nothing of. This brought him round to a qualified and ambiguous form of his original dogmas, to the effect that although there was no reason to think that God, heaven, and free-will exist, we ought to act as if they existed, and might call that wilful action of ours faith in their existence.

Thus in the philosophy of Kant there was a stimulating ambiguity in the issue. He taught rather less than he secretly believed, and his disciples, seizing the principle of his scepticism, but lacking his conservative instincts, believed rather less than he taught them. Doubtless in his private capacity Kant hoped, if he did not believe, that God, free-will, and another life subsisted in fact, as every believer had hitherto supposed; it was only the method of proving their reality that had been illegitimate. For no matter how strong the usual arguments might seem (and they did not seem very strong) they could convey no transcendent assurance; on the contrary, the more proofs you draw for anything from reason and 


\section{EGOTISM IN GERMAN PHILOSOPHY}

experience, the better you prove that that thing is a mere idea in your mind. It was almost prudent, so to speak, that God, freedom, and immortality, if they had claims to reality; should remain without witness in the sphere of "knowledge," as inadvertently or ironically it was still called; but to circumvent this compulsory lack of evidence God had at least implanted in us a veridical conscience, which if it took itself seriously (as it ought to do, being a conscience) would constrain us to postulate what, though we could never "know" it, happened to be the truth. Such was the way in which the good Kant thought to play hide-and-seek with reality.

The momentum of his transcendental method, however, led to a very different and quite egotistical conclusion. An adept in transcendentalism can hardly suppose that God, free-will, and heaven, even if he postulates them, need exist at all. Existence, for him, is an altogether inferior category. Even a specific moral law, thundering unalterable maxims, must seem to him a childish notion. What the ego postulates is nothing fixed and already existing, but only such ideal terms as, for the moment, express its attitude. If it is striving to remember, it posits. a past; if it is planning, it posits a future; if it is consciously eloquent, it posits an audience. These things do not and cannot exist otherwise than in 
their capacity of things posited by the ego. All, therefore, that the categorical imperative can mean for the complete transcendentalist is that he should live as if all things were real which are imaginatively requisite for him, if he is to live hard: this intensity of life in him being itself the only reality. At that stage of development at which Kant found himself, God, freedom, and immortality may have been necessary postulates of practical reason. But to suppose that these imagined objects, therefore, existed apart from the excellent philosopher whose conscience had not yet transcended them, would be not to have profited by his teaching. It would be merely to repeat it. A later and more advanced transcendentalist, instead of God, freedom, and immortality, might just as dutifully posit matter, empire, and the beauty of a warrior's death. His conscience might no longer be an echo of Christianity, but the trumpet-blast of a new heathenism. It is for the ego who posits to judge what it should posit.

The postulates of practical reason, by which Kant hoped to elude the subjectivity which he attributed to knowledge, are no less subjective than knowledge, and far more private and variable. The senses and the intellect, if they deceive us, seem to deceive us all in much the same way, and the dream they 


\section{EGOTISM IN GERMAN PHILOSOPHY}

plunge us into in common seems to unite us; but what obscurity, diversity, hostility in the ideals of our hearts! The postulates that were intended to save the Kantian philosophy from egotism are the most egotistical part of it. In the categorical imperative we see something native and inward to the private soul, in some of its moods, quietly claiming to rule the invisible world, to set God on his throne and open eternity to the human spirit. The most subjective of feelings, the feeling of what ought to be, legislates for the universe. Egotism could hardly go further.

But this is not all. The categorical imperative, not satisfied with proclaiming itself secretly omnipotent, proclaims itself openly ruthless. Kant expressly repudiated as unworthy of a virtuous will any consideration of happiness, or of consequences, either to oneself or to others. He was personally as mild and kindly as the Vicar of Wakefield (whose goodness he denied to be moral because it was natural), but his moral doctrine was in principle a perfect frame for fanaticism. Give back, as time was bound to give back, a little flesh to this skeleton of duty, make it the voice not of a remote Mosaic decalogue, but of a rich temperament and a young life, and you will have sanctified beforehand every stubborn passion and every romantic crime. In the guise of an infallible 
conscience, before which nothing has a right to stand, egotism is launched upon its irresponsible career.

The categorical imperative, as Kant personally conceived it, was that of the conscience of the eighteenth century, which had become humanitarian without ceasing to be Christian, the conscience of the Puritans passing into that of Rousseau. But the categorical principle in morals, like the ego in logic, can easily migrate. If to-day you are right in obeying your private conscience against all considerations of prudence or kindness (though you are prudent and kind by nature, so that this loyalty to a ruthless Duty is a sacrifice for you), to-morrow you may be right in obeying the categorical imperative of your soul in another phase, and to carry out no matter what irresponsible enterprise, though your heart may bleed at the victims you are making. The principle of fanaticism is present in either case; and Kant provides, in his transcendental agnosticism, a means of cutting off all protests from experience or common sense, or a more enlightened self-interest. These protests, he thinks, are not only ignoble, but they come from a deluded mind, since the world they regard is a creature of the imagination, whereas the categorical imperative, revealed to the inner man, is a principle prior to all worlds and, therefore, not to be corrected by any suasion which this particular 


\section{EGOTISM IN GERMAN PHILOSOPHY}

world, now imagined by us, might try to exercise on our free minds.

Thus it is from Kant, directly or indirectly, that the German egotists draw the conviction which is their most tragic-error. Their self-assertion and ambition are ancient follies of the human race; but they think these vulgar passions the creative spirit of the universe. Kant, or that soul within Kant which was still somewhat cramped in its expression, was the prophet and even the founder of the new German religion. 


\section{CHAPTER VI}

\section{TRANSCENDENTALISM PERFECTED}

Fichte purified the system of Kant of all its inconsistent and humane elements; he set forth the subjective system of knowledge and action in its frankest and most radical form. The ego, in order to live a full and free life, posited or feigned a world of circumstances, in the midst of which it might disport itself; but this imagined theatre was made to suit the play, and though it might seem to oppress the Will with all sorts of hindrances, and even to snuff it out altogether, it was really only a mirage which that Will, being wiser than it knew, had raised in order to enjoy the experience of exerting itself manfully.

It would seem obvious from this that the Will could never be defeated, and that in spite of its name it was identical with destiny or the laws of nature: and those transcendentalists who lean to naturalism, or pass into it unawares, like. Schelling or Emerson, actually understand the absolute Will in this way. But not so Fichte, nor what I take to be the keener and more heroic romantic school, whose last prophet was Nietzsche. The Germans, in 


\section{EGOTISM IN GERMAN PHILOSOPHY}

the midst of their fantastic metaphysics, sometimes surprise us by their return to immediate experience: after all, it was in wrestling with the Lord that their philosophy was begotten. As a matter of fact, the will is often defeated-especially if we are stubborn in defining our will; and this tragic fact by no means refutes the Fichtean philosophy, which knows how to deal with it heroically. It conceives that what is inviolable is only what ought to be, the unconscious plan or idea of perfect living which is hidden in the depths of all life: a will not animated in some measure by this idea cannot exist, or at least cannot be noticed or respected by this philosophy. But when, where, how often and how far this divine idea shall be carried out is left unexplained. Actual will may be feeble or wicked in any degree; and in consequence the world that ought to be evoked in its maximum conceivable richness, may dwindle and fade to nothing.

The Will may accordingly be defeated; not, indeed, by imagined external things, but by its own apathy and tergiversation. In this case, according to the logic of this system (which is as beautifully thought out as that of Plotinus), the dissolving world will appear to be overwhelmingly formidable and real. In expiring because we have no longer the warmth to keep it alive, it will seem to be killing us; for the passivity of the ego, says Fichte, is posited as activity 
in the non-ego. That way of speaking is scholastic; but the thought, if we take the egotistical point of view, is deep and true.

So any actual will may perish by defect and die out; but actual will may also perish by sublimation. The true object of absolute Will is not things or pleasures or length of life, but willing itself; and the more intense and disinterested this willing is, the better it manifests absolute Will. The heroic act of dashing oneself against overwhelming obstacles may, therefore, be the highest fulfilment of the divine idea. The will dares to perish in order to have dared everything. In its material ruin it remains ideally victorious. If we consider the matter under the form of eternity, we shall see that this heroic and suicidal will has accomplished what it willed; it has not only lived perilously but perished nobly.

It is hardly necessary to point out how completely this theory justifies any desperate enterprise to which one happens to be wedded. It justifies, for instance, any wilful handling of history and science. The Will by right lays down the principles on which things must and shall be arranged. If things slip somehow from the traces, so much the grander your "scientific deed " in striving to rein them in. After all, you first summoned them into being only that you might drive them. If they seem to run wild and upset you, 


\section{EGOTISM IN GERMAN PHILOSOPHY}

like the steeds of Hippolytus, you will, at least, not have missed the glory, while you lived and drove, of assuming the attitude of a master. Call spirits from the vasty deep: if they do not come, what of it ? That will only prove the absolute self-sufficiency of your duty to call them.

What tightens this speculative bond between Fichte and the Nietzschean school is that he himself applied his theory of absolute Will to national life. This ego, which was identical with mind in general, he identified also with the German people. If the Germans suffered their national will to be domesticated in the Napoleonic empire, the creative spirit of the universe would be extinguished, and God himself, who existed only when incarnate in mankind, would disappear. It was evidently one's duty to prevent this if possible; and Fichte poured out all the vehemence of his nature into the struggle for frecdom. The mere struggle, the mere protest in the soul, according to his system, would secure the end desired: 'self-assertion, not material success, was the goal. A happy equilibrium once established in human life would have been only a temptation, a sort of Napoleonic or Mephistophelian quietus falling on the will to strive.

I am not sure how far Fichte, in his romantic and puritan tension of soul, would have relished the 
present organisation of Germany. He was a man of the people, a radical and an agitator as much as a prophet of nationalism, and the shining armour in which German freedom is now encased might have seemed to him too ponderous. He might have discerned in victory the beginning of corruption.

Nevertheless we should remember that a perfected idealism has a tendency to change into its opposite and become a materialism for all practical purposes. Absolute Will is not a natural being, not anybody's will or thought; it is a disembodied and unrealised genius which first comes into operation when it begins to surround itself with objects and points of resistance, so as to become aware of its own stress and vocation. What these objects or felt resistances may be is not prejudged; or rather it is prejudged that they shall be most opposite to spirit, and that spirit shall experience its own passivity-one mode of its fated and requisite experience-in the form of an influence which it imputes to dead and material things.

The whole business of spirit may, therefore, well be with matter. Science might be mechanical, art might be cumbrous and material, all the instruments of life might be brutal, life itself might be hard, bitter, and obsessed, and yet the whole might remain a direct manifestation of pure spirit, absolute freedom, and creative duty. This speculative possibility 


\section{EGOTISM IN GERMAN PHILOSOPHY}

is worth noting: it helps us to understand modern Germany. It is no paradox that idealists should be so much at home among material things. These material things, according to them, are the offspring of their spirit. Why should they not sink fondly into the manipulation of philological details or chemical elements, or over-ingenious commerce and intrigue? Why should they not dote on blood and iron? Why should these fruits of the spirit be uncongenial to it?

A theoretical materialist, who looks on the natural world as on a soil that he has risen from and feeds on, may perhaps feel a certain piety towards those obscure abysses of nature that have given him birth; but his delight will be rather in the clear things of the imagination, in the humanities, by which the rude forces of nature are at once expressed and eluded. Not so the transcendentalist. Regarding his mind as the source of everything, he is moved to solemn silence and piety only before himself: on the other hand, what bewitches him, what he loves to fondle, is his progeny, the material environment, the facts, the laws, the blood, and the iron in which he conceives (quite truly, perhaps) that his spirit perfectly and freely expresses itself. To despise the world and withdraw into the realm of mind, as into a subtler and more congenial sphere, is quite contrary to his idealism. Such a retreat might bring him 
peace, and he wants war. His idealism teaches him that strife and contradiction, as Heraclitus said, are the parents of all things; and if he stopped striving; if he grew sick of ambition and material goods, he thinks he would be forsaking life, for he hates as he would death what another kind of idealists have called salvation.

We are told that God, when he had made the world, found it very good, and the transcendentalist, when he assumes the Creator's place, follows his example. The hatred and fear of matter is perhaps not a sign of a pure spirit. Even contemplatively, a divine mind may perfectly well fall in love with matter, as the Moon-goddess did with Endymion. Such matter might be imagined only, as if Diana had merely dreamt of her swain; and the fond image might not be less dear on that account. The romantic poet finds his own spirit greeting him in rocks, clouds, and waves; the musician pours out his soul in movement and tumult; why should not the transcendental general, or engineer, or commercial traveller find his purest ideal in trade, crafts, and wars? Grim work, above all, is what absolute Will demands. It needs the stimulus of resistance to become more intensely conscious of Self, which is said to be its ultimate object in imagining a world at all. Acquisition interests it more than possession, because the sense 


\section{EGOTISM IN GERMAN PHILOSOPHY}

of effort and power is then more acute. The more material the arts that engage it, and the more complicated and worldly its field of action, the more intense will be its exertion, and the greater its joy. This is no idealism for a recluse or a moping poet; it does not feel itself to be something incidental and fugitive in the world, like a bird's note, that it should fear to be drowned in the crash of material instruments or to be forced to a hideous tension and shrillness: shrillness and tension are its native element. It is convinced that it has composed all the movements there are or can be in existence, and it feels all the more masterful, the more numerous and thunderous is the orchestra it leads. It is entirely at home in a mechanical environment, which it can prove transcendentally to be perfectly ideal. Its most congenial work is to hack its way through to the execution of its World-Plan. Its most adequate and soul-satisfying expression is a universal battle. 


\section{CHAPTER VII}

\section{FICHTE ON THE MISSION OF GERMANY}

WHEN the ancient Jews enlarged their conception of Jehovah so as to recognise in him the only living God to whom all nature and history were subject, they did not cease to regard the universal power as at the same time their special national deity. Here was a latent contradiction. It was ingeniously removed by saying that Jehovah, while not essentially a tribal deity, had chosen Israel for his people by a free act of grace with no previous merit on their part; so that the pride of the Jews was not without humility.

No humility, however, is mingled with the claim which the Germans now make to a similar preeminence. "Modern critics,". says Max Stirner, "inveigh against religion because it sets up God, the divine, or the moral. law over against man, regarding them as external things, whereas the critics transform all these objects into ideas in the human mind. Nevertheless the essential mistake of religion, to assign a mission to man at all, is not avoided by these critics, who continue to insist that man shall be divine, or ideally human, or what not; morality, 


\section{EGOTISM IN GERMAN PHILOSOPHY}

freedom, humanity, etc., are his essence." Now a divinity which is subjective or immanent evidently cannot choose any nation, save by dwelling and manifesting itself more particularly in them. They can be highly favoured only in that they are intrinsically superior, and on that account may be figuratively called vessels of election. Therefore, if the spirit which is in a nation is not one spirit among many in the world (as the primitive Hebrews supposed and as a naturalistic philosophy would maintain), but is the one holy and universal spirit, and if at the same time this spirit dwells in that nation preeminently, or even exclusively, humility on the part of this nation would evidently be out of place. Accordingly, the Germans cannot help bearing witness to the divine virtues and prerogatives which they find in themselves, some of which are set forth by Fichte as follows:

The present age stands precisely in the middle of earthly time, between the era in which men were still self-seeking, earthly, and impulsive, and the coming era in which they will live for the sake of pure ideals. The Germans prefigure this better age, and are leading the rest of the world into it. They have created the modern world by uniting the political heritage of classical Europe with the true religion that lingered in Asia, and they have raised 
the two to a higher unity in their Kultur. From them is drawn the best blood of most other nations and the spiritual force that has fashioned them all.

The Germans have never forsaken their native land nor suffered seriously from immigration. Their language is primitive, and they have never exchanged it for a foreign one. Hence German alone is truly a mother-tongue. Its intellectual terms retain a vital and vivid connection with sensible experience. True poetry and philosophy, therefore, exist only in German. Captious persons who judge by mere crude feeling may fancy that German is not very melodious; but these matters cannot be rightly judged without reference to first principles, which in this case would prove that the sweetest language is that which exhausts all possible sounds and combines them in all available ways. Whether German or some other language comes nearest to this a priori ideal of euphony must be left for empirical observation to decide.

The German nature, being pure, deep, earnest, and bold, has instinctively seized upon the true essence of Christianity and discarded with abhorrence all the lies and corruption that obscured it. This essence is the imperative need of turning from the natural to the ideal life. The German knows that his own soul is safe; but this is not enough for him 


\section{EGOTISM IN GERMAN PHILOSOPHY}

in his unselfishness. His zeal is kindled easily for warmth and light everywhere; and this zeal of his is patient and efficacious, taking hold on real life and transforming it. As he presses on he finds more than he sought, for he has plunged into the quick stream of life which forges ahead of itself and carries him forward with it. The dead heart of other nations may dream of gods in the clouds, or of some perfect type of human life already exemplified in the past and only to be approached or repeated in the future. The spirit of the German is no coinage of earth; it is the living source of all the suns, and rushes to create absolutely new things for ever. The German mind is the self-consciousness of God.

I do not see that the strain of war or the intoxication of victory could add much to these boasts, uttered by Fichte when, for the moment, he had abandoned all hope of military self-assertion on the part of his country, and relied on education and philosophy alone to preserve and propagate German righteousness. Even in detail, what he says often seems strangely like what official Germany is now saying. Even the hysterical hatred of England is not absent. In England Fichte did not see the champion of Protestantism, morality, and political liberty, nor the constant foe of Napoleon, but only a universal commercial vampire. His contempt for 
the Latin races, too, was boundless. In the matter of race, indeed, he entertained a curious idea that there must have been, from all eternity until the beginning of history, a primitive Normal People, a tribe of Adams and Eves; because according to a principle which he adopted from Calvinistic theology, if all men had been originally slaves to nature none could ever have become free. This Normal People were, of course, the ancestors of the Germans. Earthborn savage tribes must have existed also for the Normal People to subdue, since but for some such conquest the primitive equilibrium would never have been broken, Eden and the jungle would never have been merged together, and history, which is a record of novelties, would never have begun. The theory of evolution has rendered the reasons for such a view obsolete; but the idea that the bulk of mankind are mongrels formed by the union of blonde godlike creatures with some sort of anthropoid blacks, recurred later in Gobineau and has had a certain vogue in Germany.

Fichte, following Calvin and Kant, made a very sharp distinction between the life of nature and that of duty. The ideal must be pursued without the least thought of advantage. Trades, he says, must be practised spontaneously, without any other reward than longer vigils. The young must never hear it 


\section{EGOTISM IN GERMAN PHILOSOPHY}

mentioned that any one could ever be incited or guided in life by the thought of his own preservation or well-being. Knowledge is no report of existing things or laws which have happened to be discovered. Knowledge is the very life of God, and self-generated. It is " an intellectual activity for its own sake, according to rules for their own sake." In plain English, it is pure imagination. But the method to be imposed on this madness is fixed innately, both for thought and for morals. Only frivolity can interfere with a unanimous idealism.

We must not suppose that this prescription of austere and abstract aims implies any aversion on Fichte's part to material progress, compulsory Kultur, or military conquest. German idealism, as we have seen, is not Platonic or ascetic, that it should leave the world behind. On the contrary, its mission is to consecrate the world and show that every part of it is an organ of the spirit. This is a form of piety akin to the Hebraic. Even the strictest Calvinists, who taught that the world was totally depraved, were able, in every sense of the phrase, to make a very good thing of it. They reclaimed, they appropriated, they almost enjoyed it. So Fichte gives us prophetic glimpses of an idealistic Germany conquering the world. The state does not aim at self-preservation, still less is it concerned to come to the aid of those 
members of the human family that lag behind the movement of the day. The dominion of unorganised physical force must be abolished by a force obedient to reason and spirit. True life consists in refashioning human relations after a model innate in the mind. The glorious destiny of Germany is to bring forth and establish the world anew. Natural freedom is a disgraceful thing, a mere medley of sensual and intellectual impulses without any principle of order. It is for the Germans to decide whether a providential progress exists by becoming themselves the providence that shall bring progress about, or whether on the contrary every higher thought is folly. If they should fail, history would never blame them, for in that case there would be no more history.

The sole animating principle of history is the tendency towards a universal Christian European monarchy. This tendency is deeper than the plans of men and stronger than their intentions. "That a state, even when on the very point of making war, should solemnly assert its love of peace and its aversion to conquest, is nothing; for in the first place it must needs make this asseveration and so hide its real intention if it would succeed in its design; and the well-known principle Threaten war that thou mayst bave peace may also be inverted in this way: Promise peace that thou mayst begin war with advantage; and 


\section{8o EGOTISM IN GERMAN PHILOSOPHY}

in the second place the state may be wholly in earnest in its peaceful assurances, so far as its selfknowledge has gone; but let the favourable opportunity for aggrandisement present itself, and the previous good resolution is forgotten."

If the people are disinclined to obey the Idea, the government must constrain them to do so. All the powers of all the citizens must be absorbed in the state. Personal liberty could be turned to no good use when such individuality and variety of training as are good for the state have been provided for by its regulations. Nor must any idleness be tolerated. An ideal education must make men over so that they shall be incapable of willing anything but what that education wills them to will. The state may then rely upon its subjects, "for whoever has a wellgrounded will, wills what he wills for all eternity."

As to foreign relations, the state, in obedience to its ideal mission, must conquer the surrounding barbarians and raise them to a state of culture. It is this process almost exclusively that has introduced progress into history. "What impels the Macedonian hero ... to seek foreign lands? What chains victory to his footsteps and scatters before him in terror the countless hordes of his enemies? Is this mere fortune? No; it is an Idea. ... . The civilised must rule and the uncivilised must obey, if Right is to be the law 
of the world. . . . Tell me not of the thousands who fell round his path; speak not of his own early death. After the realisation of his Idea, what was there greater for him to do than to die?"

This enthusiasm for Alexander (which Hegel shared) is not merely retrospective. "At last in one nation of the world the highest, purest morality, such as was never seen before among men, will arise and will be made secure for all future time, and thence will be extended over all other peoples. There will ensue a transformation of the human race from earthly and sensual creatures into pure and noble spirits." "Do you know anything higher than death ?... Who has a right to stand in the way of an enterprise begun in the face of this peril?"

It may seem curious that an uncompromising puritan like Fichte, a prophet sprung from the people, a theoretical republican who quarrelled with his students for forming clubs and fighting duels, a fierce idealist full of contempt for worldlings, should have so perfectly supplied the Junkers and bankers with their philosophy. But the phenomenon is not new. Plato, divine and urbane as he was, supplied the dull Spartans with theirs. Men of idealistic faith are confident that the foundations of things must be divine, and when, upon investigating these foundations, they come upon sinister principles-blind 


\section{EGOTISM IN GERMAN PHILOSOPHY}

impulse, chance, murderous competition - they fanatically erect these very principles into sacred maxims. All strength, they are antecedently convinced, must come from God; therefore if deception, wilfulness, tyranny, and big battalions are the means to power, they must be the chosen instruments of God on earth. In some such way the Catholic Church, too, for fear of impiety, is seen blessing many a form of deceit and oppression. Thus the most ardent speculation may come to sanction the most brutal practice. The primitive passions so sanctioned, because they seem to be safe and potent, are probably too narrowly organised to sustain themselves long; and meantime they miss and trample down the best things that mankind possesses. Nevertheless they are a force like any other, a force not only vehement but contagious, and capable of many victories though of no stable success. Such passions, and the philosophies that glorify them, are sincere, absorbing, and if frankly expressed irrefutable.

The transcendental theory of a world merely imagined by the ego, and the will that deems itself absolute are certainly desperate delusions; but not more desperate or deluded than many another system that millions have been brought to accept. The thing bears all the marks of a new religion. The fact that the established religions of Germany are still forms 
of Christianity may obscure the explicit and heathen character of the new faith: it passes for a somewhat faded speculation, or for the creed of a few extremists, when in reality it dominates the judgment and conduct of the nation. No religious tyranny could be more complete. It has its prophets in the great philosophers and historians of the last century; its high priests and pharisees in the government and the professors; its faithful flock in the disciplined mass of the nation; its heretics in the socialists; its dupes in the Catholics and the liberals, to both of whom the national creed, if they understood it, would be an abomination; it has its martyrs now by the million, and its victims among unbelievers are even more numerous, for its victims, in some degree, are all men. 


\section{CHAPTER VIII}

\section{THE EGOTISM OF IDEAS}

WHEN we are discussing egotism need we speak of Hegel? The tone of this philosopher, especially in his later writings, was full of contempt for everything subjective: the point of view of the individual, his opinions and wishes, were treated as of no account unless they had been brought into line with the providential march of events and ideas in the great world: This realism, pronounced and even acrid as it was, was still idealistic in the sense that the substance of the world was conceived not to be material but conceptual-a law or logic which animated phenomena and was the secret of their movement. The world was like a riddle or confused oracle; and the solution to the puzzle lay in the romantic instability or self-contradiction inherent in every finite form of being, which compelled it to pass into something different. The direction of this movement we might understand sympathetically in virtue of a sort of vital dialectic or dramatic necessity in our own reflection. Hegel was a solemn sophist: he made discourse the key to reality. 
This technical realism in Hegel was reinforced by his historical imagination, which continually produces an impression of detachment, objectivity, and impersonal intelligence; he often seems to be lost in the events of his story and to be plucking the very heart out of the world. Again, he adored the state, by which in his view the individual should be entirely subjugated, not for the benefit of other individuals (that would be a sort of vicarious selfishness no less barren than private profit), but in the rapt service of common impersonal ends.

The family was a first natural group in which the individual should be happy to lose himself, the tradeguild was another, and the state was the highest and most comprehensive of all; there was nothing worthy or real in a man except his functions in society.

Nevertheless this denial of egotism is apparent only. It is a play within the play. On the smaller stage the individual - save for his lapses and stammerings-is nothing but the instrument and vehicle of divine decrees; in fact he is a puppet, and the only reality of him is the space he fills in the total spectacle. But that little stage is framed in by another, often overlooked, but ever present; and on this larger and nearer stage the ego struts alone. It is I that pull the strings, enjoy the drama, supply its plot and moral, and possess the freedom and actuality which 


\section{EGOTISM IN GERMAN PHILOSOPHY}

my puppets lack. On the little stage the soul of a man is only one of God's ideas, and his whole worth lies in helping out the pantomime; on the big stage, God is simply my idea of God and the purpose of the play is to express my mind. The spectacle in which every individual dances automatically to the divine tune is only my dream.

The philosophy of Hegel is accordingly subjective and all its realism is but a pose and a tone wilfully assumed. That this is the truth of the matter might be inferred, apart from many continual hints and implications, from the fact that the system is transcendental and founded on Kant. Objectivity can, therefore, be only a show, a matter of make-believe, something imputed to things and persons by the mind, whose poetic energies it manifests. Everything must be set down as a creation of mind, simply because it is an object of thought or knowledge.

This underlying subjectivism also explains the singular satisfaction of Hegel, whose glance was comprehensive enough, with so strangely limited a world as he describes to us. He described what he knew best or had heard of most, and felt he had described the universe. This illusion was inevitable, because his principle was that the universe was created by description and resided in it. The mission of Hegel, as he himself conceived it, was not to dis- 
cover the real world or any part of it: in theory he retracted all belief in a real world and set in its place his conception or knowledge of it-therefore quite adequate to its object. If China was the oldest country he had heard of, the world began with China, and if Prussia was the youngest and he (as he had to be) its latest philosopher, the world ended with Prussia and with himself. This seems a monstrous egotism, but it is not arbitrary; in one sense it was the least pretentious of attitudes, since it was limited to the description of a current view, not of a separate or prior object. The value of a philosophy could lie only in the fullness and fidelity with which it might focus the conceptions of the age in which it arose. Hegel hoped to do this for his own times; he did not covet truth to anything further.

The same attitude explains the servility of his moral philosophy, which is simply an apology for the established order of things and for the prejudices of his time and country. His deepest conviction was that no system of ethics could be more, and if it tried to be more would be less, because it would be merely personal. When, for instance, he condemned harshly the Roman patria potestas it was because it offended the individualism of the Protestant and modern conscience; and if in the next breath he condemned even more harshly the sentimentalists. 


\section{EGOTISM IN GERMAN PHILOSOPHY}

who made tender feeling and good intentions the test of virtue, it was because these individual consciences absolved themselves from conformity to the established church and state. To inquire whether in itself or in respect to human economy generally, the morality of Buddha, or Socrates, or Rousseau was the best would have seemed to him absurd: the question could only be what approaches or contributions each of these made to the morality approved by the Lutheran community and by the Prussian ministry of education and public worship. The truth, then as now, was whatever every good German believed. This pious wish of Hegel's to interpret the orthodoxy of his generation was successful, and the modest hopes of his philosophy were fulfilled. Never perhaps was a system so true to its date and so false to its subject.

The egotism of Hegel appears also in his treatment of mathematical and physical questions. The infinite he called the false infinite, so as to avoid the dilemmas which it placed him in, such as why the evolution of the Idea began six thousand years ago, or less; what more could happen now that in his self-consciousness that evolution was complete; why it should have gone on in this planet only, or if it had gone on elsewhere also, why the Idea evolving there might not have been a different Idea. But all such questions 
are excluded when one understands that this philosophy is only a point of view: the world it describes is a vista not separable from the egotistical perspectives that frame it in. The extent of the world need not be discussed, because that extent is an appearance only; in reality the world has no extent, because it is only my present idea.

The infinite thus lost its application; but the word was too idealistic to be discarded. Accordingly the title of true infinite was bestowed on the eventual illusion of completeness, on an alleged system of relations out of relation to anything beyond. That nothing existent, unless it was the bad infinite, could be absolute in this manner did not ruffle Hegel, for the existent did not really concern him but only " knowledge," that is, a circle of present and objectless ideas. Knowledge, however limited in fact, always has the completeness in question for the egotist, whose objects are not credited with existing beyond himself. Egotism could hardly receive a more radical expression than this: to declare the ego infinite because it can never find anything that is beyond its range.

The favourite tenet of Hegel that everything involves its opposite is also a piece of egotism; for it is equivalent to making things conform to words, not words to things; and the ego, particularly in 


\section{EGOTISM IN GERMAN PHILOSOPHY}

philosophers, is a nebula of words. In defining things, if you insist on defining them, you are constrained to define them by their relation to other things, or even exclusion of them. If, therefore, things are formed by your definitions of them, these relations and exclusions will be the essence of things. The notion of such intrinsic relativity in things is a sophism even in logic, since elementary terms can never be defined yet may be perfectly well understood and arrested in intuition; but what here concerns us is rather the egotistical motive behind that sophism: namely, that the most verbal and subjective accidents to which the names of things are subject in human discourse should be deputed to be the groundwork of the things and their inmost being.

Egotistical, too, was Hegel's tireless hatred of what he called the abstract understanding. In his criticisms of this faculty and the opinions it forms there is much keenness and some justice. People often reason in the abstract, floating on words as on bladders: in their knowingness they miss the complexity and volume of real things. But the errors or abuses into which verbal intelligence may fall would never produce that implacable zeal with which Hegel persecutes it. What obsesses him is the fear that, in spite of its frivolity, the understanding may some day understand: that it may correct its inadequacies, 
trace the real movement of things, and seeing their mechanism lose that effet d'ensemble, that dramatic illusion, which he calls reason.

Imagine a landscape-painter condemned to have a naturalist always at his elbow: soon it would not be merely the errors of the naturalist that would irritate him, but the naturalist himself. The artist intent on panoramic effects does not wish to be forced to look through a microscope; in changing his focus he loses his subjective object: not reality but appearance is the reality for him. Hegel, since it was his mission to substitute so-called knowledge for being, had to go further; he had to convince himself, not only that the structure of nature discovered by the understanding was irrelevant to his own conceptual mythology, but that such a structure did not exist. He was not willing to confess (as the landscape-painter might) that he was an egotist; that it was the subjective that interested him, and that in so great a world the subjective too has its place. No! he must pretend that his egotism was not egotism, but identity with the absolute, and that those who dared to maintain that the world wagged in its own way, apart from the viewing mind, were devils, because they suggested that the viewing mind was not God.

It is this latent but colossal egotism that makes 


\section{EGOTISM IN GERMAN PHILOSOPHY}

plausible the strange use which Hegel sometimes makes of the word substance. His substance is but his grammar of discourse; for he was not looking for substance, in which he could not consistently believe, but only for the ultimate synthetic impression which he might gather from appearances. For the theatre-goer, the function of scenery and actors is that they should please and impress him: but what, in the end, impresses and pleases him? The cumulative burden and force of the play; the enhanced life which it has stimulated in himself. This, for that ruthless egotist, the æsthete, is the substance of all things theatrical. Of course, in fact, nothing could be falser, for the author and actors are real people, with lives far outrunning their function in the theatre and truly grounding it. Even the stage machinery has its natural history, and the artisans who made it have theirs, both full of mute inglorious tragedies. These real substances behind his entertainment the spectator, in his æsthetic egotism, laughs at as irrelevant; for him, as for Hamlet, the play's the thing. What is most his own, his imaginative reaction on the spectacle, the terms in which he finds it easiest and most exciting to describe it, he calls the substance of it: a term which betrays the profound impudence of the deliberate egotist; the deepest reality he will recognise is merely specious, 
existing only for the mind that imagines it. What is supposed to rescue the system of Hegel from subjectivism is the most subjective of things-a dialectic which obeys the impulses of a theoretical parti pris, and glorifies a fixed idea.

When we have understood all this, those traits of Hegel's which at first sight seem least egotisticalhis historical insight and his enthusiasm for organised society-take on a new colour. That historical insight is not really sympathetic; it is imperious, external, contemptuous, feigned. If you are a modern reading the Greeks, especially if you read them in the romantic spirit of Goethe's classicism, and know of them just what Hegel knew, you will think his description wonderfully penetrating, masterly, and complete: but would Eschylus or Plato have thought it so? They would have laughed, or rather they would not have understood that such a description referred to them at all. It is the legend of the Greeks, not the life of the Greeks, that is analysed by him. So his account of medixval religion represents the Protestant legend, not the Catholic experience. What . we know little or nothing about seems to us in Hegel admirably characterised: what we know intimately seems to us painted with the eye of a pedantic, remote, and insolent foreigner. It is but an idea of his own that he is foisting upon us, calling it our soul. 


\section{EGOTISM IN GERMAN PHILOSOPHY}

He is creating a world in his head which might be admirable, if God had made it.

Every one is subject to such illusions of perspective and to the pathos of distance, now favourable, now unfavourable to what he studies; but Hegel, thinking he had the key to the divine design, fancied himself deeply sympathetic because he saw in everything some fragment of himself. But no part of the world was that; every part had its own inalienable superiority, which to transcend was to lose for ever. To the omniscient egotist every heart is closed. The past will never give away its secret except to some selfforgetful and humble lover who by nature has a kindred destiny. The egotist who thinks to grasp it, so as to serve it up at his philosophic banquet, or exhibit it in his museum of antiquities, grasps only himself; and in that sense, to his confusion, his egotism turns out true.

The egotism that appears in this lordly way of treating the past is egotism of the imagination, the same that was expressed in the romantic love of nature, which was really a very subtle, very studious, very obstinate love of self, intent on finding some reference and deference to oneself in everything. But there is also an egotism of passion, which in Hegel appears in his worship of the state. "The passions" is the old and fit name for what the Germans call 
ideals. The passions are not selfish in the sense in which the German moralists denounce -selfishness; they are not contrived by him who harbours them for his ulterior profit. They are ideal, dangerous, often fatal. Even carnal passions are not selfish, if by the self we understand the whole man: they are an obsession to which he sacrifices himself. But the transcendental philosophy with its migratory ego can turn any single passion, or any complex of passions, into a reputed centre of will, into a moral personage. As the passion usurps more and more of the man's nature it becomes a fierce egotist in his place; it becomes fanaticism or even madness.

This substitution of a passion for a man, when nobody thought the ego migratory, seemed a disease. What folly, we said to the human soul, to sacrifice your natural life to this partial, transitory, visionary passion! But the German idealist recognises no natural life, no natural individual. His ego can migrate into any political body or any synthetic idea. Therefore, his passions, far from seeming follies to him, seem divine inspirations, calls to sacrifice, fidelities to the ideal.

I am far from wishing to say that a German idealist is commonly just to all the passions and raises them in turn to be his highest and absolute will. His passions are generally few and mental. Accidents of 


\section{EGOTISM IN GERMAN PHILOSOPHY}

training or limitations of temperament keep him respectable; but he is never safe. Dazzle him with a sophism, such, for instance, as that " the more evil the more good," or hypnotise him with a superstition, such as that "organisation is an end in itself," and nothing more is needed to turn him into a romantic criminal.

Even the absolute requires an enemy to whet its edge upon, and the state, which according to Hegel is morally absolute, requires rival states in order that its separate individuality may not seem to vanish, and with it the occasion for blessed and wholesome wars. Hegel rejects the notion that nations have any duties to one another because, as he asserts, there is no moral authority or tribunal higher than the state, to which its government could be subject. This assertion is evidently false, since in the first place there is God or, if the phrase be preferred, there is the highest good of mankind, hedging in very narrowly the path that states should follow between opposite vices; and in the second place there is the individual, whose natural allegiance to his family, friends, and religion, to truth and to art, is deeper and holier than his allegiance to the state, which for the soul of man is an historical and geographical accident. No doubt at the present stage of civilisation there is more to be gained than lost by 
co-operating loyally with the governments under which we happen to live, not because any state is divine, but because as yet no less cumbrous machinery is available for carrying on the economy of life with some approach to decency and security. For Hegel, however, the life of the state was the moral substance, and the souls of men but the accidents; and as to the judgment of God he asserted that it was none other than the course of history. This is a characteristic saying, in which he seems to proclaim the moral government of the world, when in truth he is sanctifying a brutal law of success and succession. The best government, of course, succumbs in time like the worst, and sooner; the dark ages followed upon the Roman Empire and lasted twice as long. But Hegel's God was simply the world, or a formula supposed to describe the world. He despised every ideal not destined to be realised on earth, he respected * legality more than justice, and extant institutions more than moral ideals; and he wished to flatter a government in whose policy war and even crime were recognised weapons.

This reign of official passion is not, let me repeat, egotism in the natural man who is subject to it; it is the sacrifice of the natural man and of all men to an abstract obsession, called an ideal. The vice of absoluteness and egotism is transferred 


\section{EGOTISM IN GERMAN PHILOSOPHY}

to that visionary agent. The man may be docile and gentle enough, but the demon he listens to is ruthless and deaf. It forbids him to ask, "At what price do I pursue this ideal? How much harm must I do to attain this good?" No; this imperative is categorical. The die is cast, the war against human nature and happiness is declared, and an idol that feeds on blood, the Absolute State, is set up in the heart and over the city. 


\section{CHAPTER IX}

EGOTISM AND SELFISHNESS

IN a review of egotism in German philosophy it would hardly be excusable to ignore the one notable writer who has openly adopted egotism in name as well as in fact. The work of Max Stirner on the single separate person and what he may call his own hardly belongs to German philosophy as I have been using the words: it lacks the transcendental point of departure, as well as all breadth of view, metaphysical subtlety, or generous afflatus; it is a bold, frank, and rather tiresome protest against the folly of moral idealism, against the sacrifice of the individual to any ghostly powers such as God, duty, the state, humanity, or society; all of which this redoubtable critic called "spooks" and regarded as fixed ideas and pathological obsessions. This crudity was relieved by a strong mother-wit and a dogged honesty; and it is not impossible that this poor schoolmaster, in his solitary meditations, may have embodied prophetically a rebellion against polite and religious follies which is brewing in the working classes-classes which to-morrow perhaps will absorb all mankind and give for the first time a plebeian tone to philosophy. 


\section{IOO EGOTISM IN GERMAN PHILOSOPHY}

Max Stirner called the migratory ego back to its nest. He exorcised that "spook" which had been ascending and descending the ladder of abstractions, lodged now in a single passion, now in a political body, now in a logical term, now in the outspread universe. The only true ego, he insisted, was the bodily person, the natural individual who is born and dies. No other organ or seat existed for the mind, or for any of its functions. Personal interests were the only honest interests a man could have, and if he was brow-beaten or indoctrinated into sacrificing them, that moral coercion was a scandal and a wrong. The indomitable individual should shake off those chains, which were only cobwebs, and come into his own.

Egotism thus becomes individualism, and threatens to become selfishness. The logic of these positions does not seem to have been clear to Max Stirner. That the individual must possess all his wishes and aspirations, even the most self-denying and suicidal, is obvious; he is the seat of those very obsessions and superstitions which Max Stirner deplored. The same thing is true of knowledge: a man can know only what be knows and what his faculties make him capable of knowing. This fact is the excuse for transcendentalism, and the element of truth in it. But the fact that volition and knowledge must have their 
seat in some person prejudges nothing about the scope of their objects. The fallacy of egotism begins with the inference that, therefore, a person can know only his ideas and can live only for his own benefit. On the contrary, what makes knowledge knowledge is that our sensibility may report something which is not merely our feeling; and our moral being arises when our interests likewise begin to range over the world. To deny that a man is capable of generosity because his generosity must be his own, is insufferable quibbling. Even our vanities and follies are disinterested in their way; their egotism is not a calculated selfishness. When a man orders his tomb according to his taste, it is not in the hope of enjoying his residence in it.

Max Stirner, while deprecating all subordination of the individual to society, expected people, even after they were emancipated, to form voluntary unions for specific purposes, such as playing games. Did he think that such companionship and co-operation would go without gregarious feelings and ideal interests? Would not a player wish his side to win? Would he not impose a rather painful strain upon himself at times for the sake of that "spook," victory? All the sacrifices that society or religion imposes on a man, when they are legitimate, are based on the same principle. 


\section{IO2 EGOTISM IN GERMAN PHILOSOPHY}

The protest of Max Stirner against sham ideals and aims forced upon us by social pressure should not then have extended to ideals congenial to the natural man and founded on his instincts. Since the seat of our enthusiasms must be personal, their appeal should be so too, if they are to inspire us efficaciously; but every art and science shows that they may be utterly impersonal in their object. It was not in proposing ideal aims that the German philosophers were wrong: that was the noble and heroic side of their doctrine, as well as a point in which their psychology was correct. Their error lay in defining these aims arbitrarily and imposing them absolutely, trying to thrust into us ideals like endless strife and absolute will, which perhaps our souls abhor. But if our souls abhor those things, it is because they love something else; and this other thing they love for its own sake, so that the very refusal to sacrifice to those idols is a proof of faith in a true God.

The conclusion of Max Stirner, that because those idols are false, and the worship of them is cruel and superstitious, therefore we must worship nothing and merely enjoy in a piggish way what we may call our own, is a conclusion that misreads human nature. It overlooks the fact that man lives by the imagination, that the imagination-when not chaotic and futile-is exercised in the arts of life, that the objects 
of these arts are impersonal, and that to achieve these objects brings us a natural happiness.

The Germans are by nature a good stolid people, and it is curious that their moralists, of every school, are so fantastic and bad. The trouble lies perhaps in this, that they are all precipitate. They have not taken the trouble to decipher human nature, which is an endowment, something many-sided, unconscious, with a margin of variation, and have started instead with the will, which is only an attitude, something casual, conscious, and narrowly absolute. Nor have they learned to respect sufficiently the external conditions under which human nature operates and to which it must conform-God, the material world, the nature and will of other men. Their morality consequently terminates in ideals, casual, conscious, and absolute expressions of the passions, or else expires in a mysticism which renounces all moral judgment. A reasonable morality terminates instead in the arts, by which human ideals and passions are compounded with experience and adapted to the materials they must work in. The immaturity of the German moralists appears in their conception that the good is life, which is what an irrational animal might say: whereas for a rational being the good is only the good part of life, that healthy, stable, wise, kind, and beautiful sort of life which he calls happiness. 


\section{CHAPTER $\mathrm{X}$}

THE BREACH WITH CHRISTIANITY

German philosophy has a religious spirit, but its alliance with Christianity has always been equivocal and external. Even in the speculations of Leibniz, concerned as he was about orthodoxy, there was a spirit of independence and absolutism which was rationalistic, not to say heathen. The principle of sufficient reason, for instance, demands that God and nature shall explain their existence and behaviour to us, as timid parents explain their behaviour to their censorious children. By rendering everything necessary, even the acts of God, it takes the place of God and makes him superfluous. Such frigid optimism as this principle involves, besides being fatalistic, is deeply discouraging to that hope of deliverance which is the soul of Christianity: for if this is the best world possible, how poor must be that realm of possible worlds where everything is tainted, and there is no heaven! The theory, too, that each soul contains the seeds of its whole experience and suffices for its own infinite development, destroys the meaning of creation, revelation, miracles, sin, grace, and 


\section{THE BREACH WITH CHRISTIANITY 105}

charity. Thus without intending it, even the obsequious but incredibly intelligent Leibniz undermined all the doctrines of Christianity in the act of thinking them afresh, and insinuated into them a sort of magic heathen individualism.

Kant, Fichte, and Hegel were less punctilious in their theology, but they still intended to be or to seem Christians. They felt that what made the sanctity of traditional religion and its moral force could be recovered in a purer form in their systems. This feeling of theirs was not unwarranted; at least, many religious minds, after the first shock of losing their realistic faith, have seen in transcendentalism a means, and perhaps the only safe means, of still maintaining a sort of Christianity which shall not claim any longer to be a miraculous or exceptional revelation, but only a fair enough poetic symbol for the principles found in all moral life. That he who loses his life shall save it, for instance, is a maxim much prized and much glossed by Hegelians. They lend it a meaning of their own, which might, indeed, be said to be the opposite of what the Gospel meant; for there the believer is urged to discard the very world with which Hegel asks him to identify himself. The idea is that if you surrender your private interests to those of your profession, science, or country, you become thereby a good and important person, and 


\section{Io6 EGOTISM IN GERMAN PHILOSOPHY}

unintentionally a happy one. You will then feel that the world shares your thoughts and renders them perpetual, while you, being absorbed in ideal pursuits, forget your private miseries and mortality.

In this sort of moral psychology there is evidently some truth; but the "law of experience" which it points to is but a loose and ambiguous law, which disguises more facts than it expresses. Honest minds will rebel against the suggestion that when you outgrow a desire you have fulfilled it; and they will detect the furtive irony in bidding you live hard in order not to feel the vanity of living. To drown sorrow in work, and to forget private failures in public interests, is certainly possible, but it is only drugging yourself with hurry and routine, which may not be more advantageous to others than it really is to yourself. Impersonal or "ideal" aims are not necessarily less delusive or " higher" than personal ones; in fact there is far more likelihood that they are conventional humbug. This pathological hygiene of idealism, which always stops at some uncriticised impulse, thinks it secures health when perhaps it has only increased the dose of illusion.

Nevertheless transcendentalism has this important element in common with Christianity and with the other Hebraic religions, that it regards human interests as the core of the universe and God as the 
God of man, who disposes all things for man's benefit. In its eyes the sphere of providence and moral life is bounded by the history of a part of Europe and Asia for a few thousand years. So long as transcendentalism is taken to imply some such philosophy of history it can compound its differences with liberal Christianity, since they are at one in the cardinal point of their faith, which is the apotheosis of the human spirit.

Yet this human egotism, which comforts so many minds, offends others, in their way no less religious. Of course, those who believe in the infinity of the universe, be they mystics or naturalists, smile at such pettiness and fatuity. But even among transcendentalists, some are repelled; for the dominion which they attribute to their ego is a dominion over appearances only; they do not pretend that the grammar of the human intellect can lay down the law for the world at large. At the same time, in their own house they wish to keep their freedom. That prescribed evolution and that reversible optimism of the absolute transcendentalists are repulsive to them; they resent that such a precise and distasteful career should be imposed on their transcendental individuality, and should swallow it up. It is these rebels that have carried romanticism and German philosophy into its last phase. They have broken at 


\section{EGOTISM IN GERMAN PHILOSOPHY}

last with Christianity and at the same time with the theological and cosmic transcendentalism that was its treacherous ally, and hoped to be its heir.

The transcendentalism of Schopenhauer, sweeping as it was in its way, retained the modest and agnostic character it had had in Kant: he proclaimed that the world was his idea, but meant only (what is undeniable) that his idea of the world was his idea. The egotistical doctrine that the whole universe is but the image of it created by the mind disappeared altogether in his system. The so-called Will which he still placed behind everything was no longer his own will evolving experience out of nothing; it was a fanciful name for whatever force or substance might lie behind experience, animating all its objects, determining their inherent life, and constituting them facts collateral with himself. If his metaphysics remained idealistic, it was on account of his romantic habit of assimilating the life of nature to that of man, as hasty introspection reveals it; so that the universe is described in moral and poetical terms rather than in the terms of science.

The consequences of this change were important. The Will became infinite in what Hegel called the evil sense, that is, in the true one. It was no longer possible to speak of a plan of creation, nor of a dramatic progress in history, with its beginning in 


\section{THE BREACH WITH CHRISTIANITY IO9}

Eden and its end in Berlin. Life was seen to radiate, as it really does, from an elementary form into all sorts of disparate and incomparable growths, capable of endless diversity. No limit, no forced co-operation, no stereotyped method was imputed to life. The pocket universe of Hegel opened out to the stars, so hateful to that philosopher. Man lost his importance and at the same time the insufferable burden of his false pretensions. In Schopenhauer frankness returned, and with frankness clearness. Yet he could not quite reconcile man to his actual place in nature. A deep prejudice still intervened.

Both Christianity and romanticism had accustomed people to disregard the intrinsic value of things. Things ought to be useful for salvation, or symbols of other greater but unknown things: it was not to be expected that they should be simply good in themselves. This life was to be justified, if justified at all, only as servile work or tedious business may be justified, not as health or artistic expression justify themselves. Unless some external and ulterior end could be achieved by living, it was thought that life would be vanity. Remove now the expectation of a millennium or of a paradise in the sky, and it may seem that all serious value has disappeared from our earthly existence. Yet this feeling is only a temporary after-image of a particular education. 


\section{IIO EGOTISM IN GERMAN PHILOSOPHY}

The romantic poets, through pride, restlessness, and longing for vague impossible things, came to the same conclusion that the church had reached through censoriousness and hope. To be always dissatisfied seemed to that Faust-like age a mark of loftiness. To be dissatisfied is, indeed, a healthy and promising thing, when what troubles us can be set right; but the romantic mind despises such incidental improvements which far from freeing the wild egotistical soul would rather fatten and harness it. It is beneath the romantic pessimist to remember that people, in all ages, sometimes achieve what they have set their hearts on, and that if human will and conduct were better disciplined, this contentment would be more frequent and more massive. On the contrary, he asserts that willing is always and everywhere abortive.

How can he persuade himself of something so evidently false? By that mystical misinterpretation of human nature which is perhaps the core of romanticism. He imagines that what is desired is not this or that-food, children, victory, knowledge, or some other specific goal of a human instinct-but an abstract and perpetual happiness behind all these alternating interests. Of course an abstract and perpetual happiness is impossible, not merely because events are sure to disturb any equilibrium we may think we have established in our lives, but for the 


\section{THE BREACH WITH CHRISTIANITY III}

far more fundamental reason that we have no abstract and perpetual instinct to satisfy. The desire for selfpreservation or power or union with God is no more perpetual or comprehensive than any other: it is commonly when we are in straits that we become aware of such objects, and to achieve them, or imagine we achieve them, will give us only a momentary satisfaction, like any other success. A highest good to be obtained apart from each and every specific interest is more than unattainable; it is unthinkable. The romanticist, chasing wilfully that ignis fatuus, naturally finds his life arduous and disappointing. But he might have learned from Plato or any sound moralist, if his genius could allow him to learn anything, that the highest good of man is the sum and harmony of those specific goods upon which his nature is directed. But because the romantic will was unteachable, all will was declared to be foolish.

Schopenhauer was led into his pessimism also by the spirit of opposition; his righteous wrath was aroused by the sardonic and inhuman optimism of Hegel, the arguments for which were so cogent, so Calvinistic, and so irrelevant that they would have lost none of their force if they had been proposed in hell. The best possible world and the worst possible world are, indeed, identical for that philosophy. Schopenhauer needed to change nothing in the 


\section{EGOTISM IN GERMAN PHILOSOPHY}

description of life, as the other idealists conceived it, in order to prove that life was a tragedy; for they were as romantic as himself and as far from feeling the intrinsic value of happiness, and the possibility of real progress. Real progress has little to do with perpetual evolution. It occurs only in certain places and times, when nature or art comes to the assistance of some definite interest already embodied, as the interest in security and mutual confidence, knowledge, or the fine arts is already embodied in mankind. Schopenhauer was not insensible to these achievements; he felt by instinct the infinity and luxuriance of the moral world. It was in part this secret sympathy with nature that alienated him from Christianity and from transcendental metaphysics. But because natural goods cannot be desired or possessed for ever, he thought their value was cancelled, even for those who desired and possessed them. The leaven of romanticism was still at work, forbidding him to recognise a natural order, with which a vital harmony might be established. The ground of life, the Will in all things, was something lurid and tempestuous, itself a psychological chaos. The alternative to theism in the mind of Schopenhauer was not naturalism but anarchy.

This romantic travesty of life and this conception of metaphysical anarchy were inherited by Nietzsche 
and regarded by him as the last word of philosophy. But he made the breach with Christianity still wider. The grief of Schopenhauer in the presence of such a world, his desperate and exotic remedy-the denial of the will-and his love of contemplation were all evidences of a mind still half Christian : his pessimism itself was so much homage to the faith he had lost. Such backward glances were not for the impetuous Nietzsche, who felt he was a prophet of the future, and really was one. Romantic anarchy delighted him; and he crowned it with a rakish optimism, as with the red cap of Liberty. He was in hearty sympathy with absolute Will; he praised it even for being vain and maleficent, if it was only proud enough to praise itself. 


\section{CHAPTER XI}

\section{NIETZSCHE AND SCHOPENHAUER}

Ir is hardly fair to a writer like Nietzsche, so poetical, fragmentary, and immature, to judge him as a philosopher; yet he wished to be so judged, and planned a system which was to be an emendation of that of Schopenhauer. The will to live would become the will to dominate; pessimism founded on reflection would become optimism founded on courage; the suspense of the will in contemplation would yield to a more biological account of intelligence and taste; finally in the place of pity and asceticism (Schopenhauer's two principles of morals) Nietzsche would set up the duty of asserting the will at all costs and being cruelly but beautifully strong.

These points of difference from Schopenhauer cover the whole philosophy of Nietzsche. I will consider them in order, leaving the last for the next chapter.

The change from "the will to live" to "the will to be powerful" is only a change of metaphors: both are used merely to indicate the general movement of nature. The choice of a psychological symbol for this purpose is indifferent scientifically, since the 
NIETZSCHE AND SCHOPENHAUER II5

facts in any case remain the same and our knowledge of them is not enlarged; yet it is an interesting indication of the mind of the poet using it, because whatever a man knows and loves best, that he takes his metaphors from. Nietzsche had his reasons for liking to call the universal principle a lust for power. He believed he was the herald of two hundred years of war, he was in love with the vague image of a military aristocracy, and he was not without a certain biological acumen.

An acorn in the ground does not strive to persevere in the state it happens to be in, but expands, absorbs surrounding elements, and transforms them into its own substance, which itself changes its form. Here then is a will to grow, not simply a will to live or to preserve oneself; in fact, as Nietzsche eloquently said, here is a will to perish. It is true that when the oak is full grown it seems to pass to the defensive and no longer manifests the will either to perish or to grow. Even while the will to grow is operating, its scope is not indefinite. It would be grotesque to imagine that the acorn, like the ego of German philosophy, tended to annex the whole earth and the whole sky and to make a single oak of the universe. If we take a broad view, perhaps the ancient myth that nature tends to re-embody certain fixed types, though inaccurate, gives a better picture of the facts than 


\section{I16 EGOTISM IN GERMAN PHILOSOPHY}

the modern myth that she is striving to change in one predetermined direction. Nevertheless, the fact that Nietzsche's attention was fascinated by the will to grow and to dominate shows that he was in sympathy with young things, that his heart was big with the future, and that his age believed in progress.

The change from pessimism to optimism, verbally so complete, did not imply any divergence between Nietzsche and Schopenhauer in their description of the facts; it was all a matter of a little more spirit in the younger thinker and a little more conscience in the elder. Romantic poets and their heroes are well known to oscillate between passionate despair and passionate enterprise. Schopenhauer affected passionate despair, Nietzsche recommended passionate enterprise, each being wedded exclusively to one of those moods which Faust or Byron could feel alternately and reduce to act with all the dashing tumult of anarchy. The value which the world has in the eyes of its inhabitants is necessarily mixed, so that a sweeping optimism or pessimism can be only a theoretic pose, false to the natural sentiment even of those who assume it. Both are impressionistic judgments passed on the world at large, not perhaps without some impertinence.

Yet it is these poses or attitudes, or, if you like, these impertinences, that give importance to tran- 
scendental philosophers; it is their representative and contagious side; their views of things would concern us little, if it was the things themselves that we wished to understand, but our whole study is a study in romanticism. The temper of the age ignored that man is a teachable animal living in a natural world. All that was a vulgar convention; in truth a disembodied Will was directed on any and every ideal at random, and when any of these fantastic objects seemed to be attained nothing was really accomplished, nothing was accumulated or learned. The wish for some other will-o'-the-wisp immediately succeeded, always equally passionate and equally foolish.

It is amazing that such a picture of human experience should have met with anything but general derision; but when people read books they compare them with other books, and when they turn to things they forget books altogether. Hence the most palpable falsehoods are held by general consent at certain moments, because they follow logically from what the books of the previous generation had maintained. This absurdity of Schopenhauer's is a plausible variation of idealism; to see how absurd it is you must remember the facts of life, the existence of any degree of civilisation or progress. In these the travail of human nature appears; for human nature is not 


\section{I18 EGOTISM IN GERMAN PHILOSOPHY}

merely a name for a certain set of passions known to literature; in that sense Schopenhauer fully acknowledged it, and even thought it immutable; it is rather the constitution of an animal capable of training and development. What is more patent than that a man may learn something by experience and may be trained? But if he can be trained he is capable of adaptation and, therefore, of happiness, and the preposterous assertion that all desires are equally arbitrary and equally fruitless is blown to the winds.

The belief in a romantic chaos lends itself to pessimism, but it also lends itself to absolute selfassertion. Kant had boasted that he had removed knowledge in order to make room for faith; in other words, he had returned to chaos in order to find freedom. The great egotists, who detested the pressure of a world they had not posited or created, followed gladly in that path; but Schopenhauer was not an egotist. Like Goethe he was probably more selfish personally than those other philosophers whom their very egotism had made zealous and singleminded; but in imagination and feeling he was, like Goethe, genial and humane: the freedom and exuberance of nature impressed him more than his own. Had he been an egotist, as Fichte, Hegel, and Nietzsche were, he might have been an optimist like them. He was rather a happy man, hugely enjoying 
a great many things, among them food and music; and he taught that music was a direct transcript of the tormented will to live. How simple it would have been for him, if he had been an egotist, to enjoy the spectacle of that tormented will as much as the music which was its faithful image! But no; such æsthetic cruelty, which was Nietzsche's delight, would have revolted Schopenhauer. He thought tragedy beautiful because it detached us from a troubled world and did not think a troubled world good, as those unspeakable optimists did, because it made such a fine tragedy. It is pleasant to find that among all these philosophers one at least was a gentleman.

If Will is the sole substance or force in the universe, it must be present in everything that exists, yet Schopenhauer affirmed that it was absent in æsthetic contemplation; and he looked to an ultimate denial of the Will, which if it was to be an act and not merely a void would evidently be impossible on his principles. The Will might well say to those who attempted to deny it: "They reckon ill who leave me out; when me they fly, I am the wings." In perceiving and correcting this contradiction, Nietzsche certainly improved the technique of the system.

Yet that contradiction was not substantial; it was verbal merely, and due to the fond use of the term 


\section{EGOTISM IN GERMAN PHILOSOPHY}

Will for what might more properly be called matter, energy, or movement. Will taken in the metaphorical sense can never be in abeyance, so long as anything is going on; but will taken in its proper sense is in abeyance often; and this is what Schopenhauer saw and meant to say. Actual and conscious will is a passing phenomenon; it is so little necessary to life that it always disappears when life is at its height. All pure pleasures, including those of seeing and thinking, are without it: they are ingenuous, and terminate in their present object. A philosopher should have learned from Aristotle, if not from his own experience, that at the acme of life we live in the eternal, and that then, as Schopenhauer said, we no longer pry but gaze, and are freed from willing.

This is not to say that Nietzsche was not very happy and witty in his description of the passions that dominate artists and philosophers, and in urging that the life of the spirit was an impassioned thing. To prove it, he might have quoted Schopenhauer himself, in those moving passages where he describes the ecstasy of thought and the spell of beauty. It is not the dead or the bloodless that have such feelings. Of course, if the operations of the brain, and the whole instinctive life of the soul, were interrupted neither these feelings nor any others would arise. This was at bottom Schopenhauer's conviction. His 
great intuition, the corner-stone of his philosophy, was precisely the priority of automatism and instinct over the intellect. His only error came from having given to these underlying processes the name of Will, when properly the will is one expression of them only, as the intellect is.

Nietzsche, who adopted the same metaphor, was led by it into the very confusion which he criticised in Schopenhauer. Nietzsche had no great technical competence: he saw the inconsistency only when he disliked the result; when the result fell in with his first impressions he repeated the inconsistency. $\mathrm{He}$ often condemned other moralists for being enemies to life: he reproached the greater part of mankind for loving inglorious ease and resenting the sufferings inseparable from the will to be mighty and to perish. But this churlish attitude of the vulgar would be quite impossible if the heroic will to be powerful were the essence of everybody and even of material things. If I am nothing but the will to grow, how can I ever will to shrink?

But this inconsistency in Nietzsche, like that in Schopenhauer, was an honourable one that came of forgetting a false generalisation in the presence of a clear fact. That the will to be powerful is everywhere was a false generalisation; but it was a clear fact that some people are pious Christians or Epicurean 


\section{EGOTISM IN GERMAN PHILOSOPHY}

philosophers, who do not care at all about conquering the world. They want to be let alone, and perhaps have a shrewd suspicion that no one lives under such dire compulsions as he who undertakes to tyrannise over others. This slave-morality of theirs might be called Will, though it is rather instinct and habit; but it is certainly not a will to be powerful: it is the opposite of that passion. Thus Nietzsche, by an honest self-contradiction, pointed to people who denied the will to be powerful, in order to abuse them, just as Schopenhauer had pointed to people who denied or suspended the will to live, in order to praise them. 


\section{CHAPTER XII}

\section{THE ETHICS OF NIETZSCHE}

Nietzsche occasionally spoke disparagingly of morality, as if the word and the thing had got a little on his nerves; and some of his best-known phrases might give the impression that he wished to drop the distinction between good and evil and transcend ethics altogether. Such a thought would not have been absurd in itself or even unphilosophical. Many serious thinkers, Spinoza for instance, have believed that everything that happens is equally necessary and equally expressive of the will of God, be it favourable or unfavourable to our special interests and, therefore, called by us good or bad. A too reverent immersion in nature and history convinces them that to think any part of reality better or worse than the rest is impertinent or even impious. It is true that in the end these philosophers usually stultify themselves and declare enthusiastically that whatever is is right. This rapturous feeling can overcome anybody in certain moods, as it sometimes overcame Nietzsche; but in yielding to it, besides contradicting all other moral judgments, these mystics break their difficult resolution never to judge at all. 


\section{EGOTISM IN GERMAN PHILOSOPHY}

Nietzsche, however, was entirely free from this divine impediment in morals. The courage to cling to what his soul loved-and this courage is the essence of morality-was conspicuous in him. He was a poet, a critic, a lover of form and of distinctions. Few persons have ever given such fierce importance to their personal taste. What he disliked to think of, say democracy, he condemned with the fulminations of a god; what he liked to think of, power, he seriously commanded man and nature to pursue for their single object.

What Nietzsche disparaged, then, under the name of morality was not all morality, for he had an enthusiastic master-morality of his own to impose. He was thinking only of the Christian virtues and especially of a certain Protestant and Kantian moralism with which perhaps he had been surfeited. This moralism conceived that duty was something absolute and not a method of securing whatever goods of all sorts are attainable by action. The latter is the common and the sound opinion, maintained, for instance, by Aristotle; but Nietzsche, who was not humble enough to learn very much by study, thought he was propounding a revolutionary doctrine when he put goods and evils beyond and above right and wrong: for this is all that his fenseits von Gut und Böse amounts to. Whatever seemed to him 
admirable, beautiful, eligible, whatever was good in the sense opposed not to böse but to schlecht, Nietzsche loved with jealous affection. Hence his ire against Christianity, which he thought renounced too much. Hence his hatred of moralism, which in raising duty to the irresponsible throne of the absolute had superstitiously sacrificed half the goods of life. Nietzsche, then, far from transcending ethics, re-established it on its true foundations, which is not to say that the sketchy edifice which he planned to raise on these foundations was in a beautiful style of architecture or could stand at all.

The first principle of his ethics was that the good is power. But this word power seems to have had a great range of meanings in his mind. Sometimes it suggests animal strength and size, as in the big blonde beast; sometimes vitality, sometimes fortitude, sometimes contempt for the will of others, sometimes (and this is perhaps the meaning he chiefly intended) dominion over natural forces and over the people, that is to say, wealth and military power. It is characteristic of this whole school that it confuses the laws which are supposed to preside over the movement of things with the good results which they may involve; so Nietzsche confuses his biological insight, that all life is the assertion of some sort of power-the power to breathe, for instance-with the 


\section{EGOTISM IN GERMAN PHILOSOPHY}

admiration he felt for a masterful egotism. But even if we identify life or any kind of existence with the exertion of strength, the kinds of strength exerted will be heterogeneous and not always compatible. The strength of Lucifer does not insure victory in war; it points rather to failure in a world peopled by millions of timid, pious, and democratic persons. Hence we find Nietzsche asking himself plaintively, "Why are the feeble victorious?" The fact rankled in his bosom that in the ancient world martial aristocracies had succumbed before Christianity, and in the modern world before democracy. By strength, then, he could not mean the power to survive, by being as flexible as circumstances may require. He did not refer to the strength of majorities, nor to the strength of vermin. At the same time he did not refer to moral strength, for of moral strength he had no idea.

The arts give power, but only in channels prescribed by their own principles, not by the will of untrained men. To be trained is to be tamed and harnessed, an accession of power detestable to Nietzsche. His Zarathustra had the power of dancing, also of charming serpents and eagles: no wonder that he missed the power, bestowed by goodness, of charming and guiding men; and a Terpsichorean autocrat would be hard to imagine. A man intent on algebra 
or on painting is not striving to rule anybody; his dominion over painting or algebra is chiefly a matter of concentration and self-forgetfulness. So dominion over the passions changes them from attempts to appropriate anything into sentiments of the mind, colouring a world which is no longer coveted. To attain such autumnal wisdom is, if you like, itself a power of feeling and a kind of strength; but it is not helpful in conquering the earth.

Nietzsche was personally more philosophical than his philosophy. His talk about power, harshness, and superb immorality was the hobby of a harmless young scholar and constitutional invalid. $\mathrm{He}$ did not crave in the least either wealth or empire. What he loved was solitude, nature, music, books. But his imagination, like his judgment, was captious; it could not dwell on reality, but reacted furiously against it. Accordingly, when he speaks of the will to be powerful, power is merely an eloquent word on his lips. It symbolises the escape from mediocrity. What power would be when attained and exercised remains entirely beyond his horizon. What meets us everywhere is the sense of impotence and a passionate rebellion against it.

The phrases in which Nietzsche condensed and felt his thought were brilliant, but they were seldom just. We may perhaps see the principle of his ethics 


\section{EGOTISM IN GERMAN PHILOSOPHY}

better if we forget for a moment the will to be powerful and consider this: that he knew no sort of good except the beautiful, and no sort of beauty except romantic stress. He was a belated prophet of romanticism. He wrote its epitaph, in which he praised it more extravagantly than anybody, when it was alive, had had the courage to do.

Consider, for example, what he said about truth. Since men were governed solely by the will to be powerful, the truth for its own sake must be moonshine to them. They would wish to cultivate such ideas, whether true or false, as might be useful to their ambition. Nietzsche (more candid in this than some other pragmatists) confessed that truth itself did not interest him; it was ugly; the bracing atmosphere of falsehood, passion, and subjective perspectives was the better thing. Sometimes, indeed, a more wistful mood overtook him, and he wondered whether the human mind would be able to endure the light of truth. That was the great question of the future. We may agree that a mind without poetry, fiction, and subjective colouring would not be human, nor a mind at all; and that neither truth nor the knowledge of truth would have any intrinsic value if nobody cared about it for its own sake. But some men do care; and in ignoring this fact Nietzsche expresses the false and pitiful notion that we can be 
interested in nothing except in ourselves and our own future. I am solitary, says the romantic egotist, and sufficient unto myself. The world is my idea, new every day: what can I have to do with truth?

This impulse to turn one's back on truth, whether in contempt or in despair, has a long history. Lessing had said that he preferred the pursuit of truth to the truth itself; but if we take this seriously (as possibly it was not meant) the pursuit of truth at once changes its character. It can no longer be the pursuit of truth, truth not being wanted, but only the pursuit of some fresh idea. Whether one of these ideas or another comes nearer to the truth would be unimportant and undiscoverable. Any idea will do, so long as it is pregnant with another that may presently take its place; and as presumably error will precipitate new ideas more readily than truth, we might almost find it implied in Lessing's maxim that, as Nietzsche maintained, what is really good is neither truth nor the pursuit of truth (for you might find it, and what would you do then?), but rather a perpetual flux of errors.

This view is also implied in the very prevalent habit of regarding opinions as justified not by their object but by their date. The intellectual ignominy of believing what we believe simply because of the time and place of our birth, escapes many evolu- 


\section{I30 EGOTISM IN GERMAN PHILOSOPHY}

tionists. Far from trying to overcome this natural prejudice of position, they raise it into a point of pride. They declare all opinions ever held in the past to be superseded, and are apparently content that their own should be superseded to-morrow, but meantime they cover you with obloquy if you are so backward or so forward as not to agree with them to-day. They accept as inevitable the total dominion of the point of view. Each new date, even in the life of an individual thinker, is expected by them to mark a new phase of doctrine. Indeed, truth is an object which transcendental philosophy cannot envisage: the absolute ego must be satisfied with consistency. How should the truth, actual, natural, or divine, be an expression of the living will that attempts, or in their case despairs, to discover it? Yet that everything, even the truth, is an expression of the living will, is the corner-stone of this philosophy.

Consider further the spirit in which Nietzsche condemned Christianity and the Christian virtues. Many people have denounced Christianity on the ground that it was false or tyrannical, while perhaps admitting that it was comforting or had a good moral influence. Nietzsche denounced it-and in unmeasured terms-on the ground that (while, of course, as true as any other vital lie) it was mean, depressing, slavish, and plebeian. How beastly was 
the precept of love! Actually to love all these grotesque bipeds was degrading. A lover of the beautiful must wish almost all his neighbours out of the way. Compassion, too, was a lamentable way of assimilating oneself to evil. That contagious misery spoiled one's joy, freedom, and courage. Disease should not be nursed but cauterised; the world must be made clean.

Now there is a sort of love of mankind, a jealous love of what man might be, in this much decried maxim of unmercifulness. Nietzsche rebelled at the thought of endless wretchedness, pervasive mediocrity, crying children, domestic drudges, and pompous fools for ever. Die Erde war zu lange schon ein Irrenbaus! His heart was tender enough, but his imagination was impatient. When he praised cruelty, it was on the ground that art was cruel, that it made beauty out of suffering. Suffering, therefore, was good, and so was crime, which made life keener. Only crime, he said, raises a man high enough for the lightning to strike him. In the hope of sparing some obscure person a few groans or tears, would you deprive the romantic hero of so sublime a death?

Christians, too, might say they had their heroes, their saints; but what sort of eminence was that? It was produced by stifling half the passions. A 


\section{I32 EGOTISM IN GERMAN PHILOSOPHY}

sister of charity could not be an Arminius; devotion to such remedial offices spoilt the glory of life. Holiness was immoral; it was a half-suicide. All experience, the ideal of Faust, was what a spirited man must desire. All experience would involve, I suppose, passing through all the sensations of a murderer, a maniac, and a toad; even through those of a saint or a sister of charity. But the romantic mind despises results; it is satisfied with poses.

Consider, too, the romantic demand for a violent chiaroscuro, a demand which blossoms into a whole system of ethics. Good and evil, we are told, enhance one another, like light and shade in a picture; without evil there can be no good, so to diminish the one is to undermine the other, and the greatest and most heroic man is he who not only does most good but also most harm. In his love of mischief, in his tenderness for the adventurer who boldly inflicts injury and suffering on others and on himself, in order to cut a more thrilling and stupendous figure in his own eyes, Nietzsche gave this pernicious doctrine its frankest expression; but unfortunately it was not wholly his own. In its essence it belongs to Hegel, and under various sophistical disguises it has been adopted by all his academic followers in England and America. The arguments used to defend it are old sophisms borrowed from the Stoics, who 
had turned the physical doctrine of Heraclitus, that everything is a mixture of contraries, into an argument for resignation to inevitable evils and detachment from tainted goods. The Stoics, who were neither romantic nor worldly, used these sophisms in an attempt to extirpate the passions, not to justify them. They were sufficiently refuted by the excellent Plutarch where he observes that according to this logic it was requisite and necessary that Thersites should be bald in order that Achilles might have leonine hair. The absurdity is, indeed, ludicrous, if we are thinking of real things and of the goods and evils of experience; but egotists never think of that; what they always think of is the picture of those realities in their imagination. For the observer, effects of contrast do alter the values of the elements considered; and, indeed, the elements themselves, if one is very unsympathetic, may not have at all in contemplation the quality they have in experience: whence æsthetic cruelty. The respect which Hegel and Nietzsche have for those sophisms becomes intelligible when we remember what imperturbable egotists they were.

This egotism in morals is partly mystical. There is a luxurious joy in healing the smart of evil in one's mind, without needing to remove or diminish the evil in the world. The smart may be healed by 


\section{I34 EGOTISM IN GERMAN PHILOSOPHY}

nursing the conviction that evil after all is good, no matter how much of it there is or how much of it we do. In part, however, this egotism is romantic; it does not ask to be persuaded that evil, in the end, is good. It feels that evil is good in the present; it is so intense a thing, to feel and so exciting a thing to do. Here we have what Nietzsche wished to bring about, a reversal of all values. To do evil is the true virtue, and to be good is the most hopeless vice. Milk is for babes; your strong man should be soaked in blood and in alcohol. We should live perilously; and as material life is the power to digest poisons, so true excellence is the power to commit all manner of crimes, and to survive.

That there is no God is proved by Nietzsche pragmatically, on the ground that belief in the existence of God would have made him uncomfortable. Not at all for the reason that might first occur to us: to imagine himself a lost soul has always been a point of pride with the romantic genius. The reason was that if there had been any gods he would have found it intolerable not to be a god himself. Poor Nietzsche! The laurels of the Almighty would not let him sleep.

It is hard to know if we should be more deceived in taking these sallies seriously or in not taking them so. On the one hand it all seems the swagger 
of an immature, half-playful mind, like a child that tells you he will cut your head off. The dreamy impulse, in its inception, is sincere enough, but there is no vestige of any understanding of what it proposes, of its conditions, or of its results. On the other hand these explosions are symptomatic; there stirs behind them unmistakably an elemental force. That an attitude is foolish, incoherent, disastrous, proves nothing against the depth of the instinct that inspires it. Who could be more intensely unintelligent than Luther or Rousseau? Yet the world followed them, not to turn back. The molecular forces of society, so to speak, had already undermined the systems which these men denounced. If the systems have survived it is only because the reformers, in their intellectual helplessness, could supply nothing to take their place. So Nietzsche, in his genial imbecility, betrays the shifting of great subterranean forces. What he said may be nothing, but the fact that he said it is all-important. Out of such wild intuitions, because the heart of the child was in them, the man of the future may have to build his philosophy. We should forgive Nietzsche his boyish blasphemies. He hated with clearness, if he did not know what to love. 


\section{CHAPTER XIII}

\section{THE SUPERMAN}

In his views on matters of fact Nietzsche, as becomes the naive egotist, was quite irresponsible. If he said the course of history repeated itself in cycles, it was because the idea pleased him; it seemed a symbol of self-approval on the world's part. If he hailed the advent of a race of men superior to ourselves and of stronger fibre, it was because human life as it is, and especially his own life, repelled him. He was sensitive and, therefore, censorious. He gazed about him, he gazed at himself, he remembered the disappointing frailties and pomposity of the great man, Wagner, whom he had once idolised. His optimism for the moment yielded to his sincerity. He would sooner abolish than condone such a world, and he fled to some solitary hillside by the sea, saying to himself that man was a creature to be superseded.

Dissatisfaction with the actual is what usually leads people to frame ideals at all, or at least to hold them fast; but such a negative motive leaves the ideal vague and without consistency. If we could suddenly have our will, we should very likely find the result trivial or horrible. So the superman of r36 
Nietzsche might prove, if by magic he could be realised. To frame solid ideals, which would, in fact, be better than actual things, is not granted to the merely irritable poet; it is granted only to the masterworkman, to the modeller of some given substance to some given use-things which define his aspiration, and separate what is relevant and glorious in his dreams from that large part of them which is merely ignorant and peevish. It was not for Nietzsche to be an artist in morals and to institute anything coherent, even in idea.

The superman of Nietzsche is rendered the more chimerical by the fact that he must contradict not only the common man of the present but also the superior men, the half-superhuman men, of the past. To transcend humanity is no new ambition; that has always been the effort of Indian and Christian religious discipline and of Stoic philosophy. But this spiritual superiority, like that of artists and poets, has come of abstraction; a superiority to life, in that these minds were engrossed in the picture or lesson of life rather than in living; and if they powerfully affected the world, as they sometimes did, it was by bringing down into it something supermundane, the arresting touch of an ulterior wisdom. Nietzsche, on the contrary, even more than most modern philosophers, loved mere life with the pathetic intensity of 


\section{I38 EGOTISM IN GERMAN PHILOSOPHY}

the wounded beast; his superman must not rise above our common condition by his purely spiritual resources, or by laying up his treasure in any sort of heaven. He must be not a superior man but a kind of physiological superman, a griffin in soul, if not in body, who instead of labouring hands and religious faith should have eagle's wings and the claws of a lion. His powers should be superior to ours by resembling those of fiercer and wilder animals. The things that make a man tame-Nietzsche was a retired professor living in a boarding-house-must be changed into their opposites. But man has been tamed by agriculture, material arts, children, experience; therefore these things are to be far from the superman. If he must resemble somebody, it will be rather the condottieri of the renaissance or the princes and courtiers of the seventeenth century; Cæsar Borgia is the supreme instance. He must have a splendid presence and address, gallantry, contempt for convention, loyalty to no country, no woman, and no idea, but always a buoyant and lordly assertion of instinct and of self. In the helter-skelter of his irritable genius, Nietzsche jumbled together the ferocity of solitary beasts, the indifference and bauteur of patricians, and the antics of revellers, and out of that mixture he hoped to evoke the rulers of the coming age. 
How could so fantastic an ideal impose on a keen satirist like Nietzsche and a sincere lover of excellence? Because true human excellence seemed to him hostile to life, and he felt-this was his strong and sane side, his lien on the future-that life must be accepted as it is or may become, and false beliefs, hollow demands, and hypocritical, forced virtues must be abandoned. This new wisdom was that which Goethe, too, had felt and practised; and of all masters of life Goethe was the one whom Nietzsche could best understand. But a master of life, without being in the least hostile to life, since he fulfils it, nevertheless uses life for ends which transcend it. Even Goethe, omnivorous and bland as he was, transcended life in depicting and judging and blessing it. The saints and the true philosophers have naturally emphasised more this renunciation of egotism: they have seen all things in the light of eternity - that is, as they are in truth-and have consequently felt a reasonable contempt for mere living and mere dying; and in that precisely lies moral greatness. Here Nietzsche could not follow; rationality chilled him; he craved vehemence.

How life can be fulfilled and made beautiful by reason was never better shown than by the Greeks, both by precept and example. Nietzsche in his youth was a professor of Greek literature: one would have 


\section{I40 EGOTISM IN GERMAN PHILOSOPHY}

expected his superman to be a sort of Greek hero. Something of the Dorian harshness in beauty, something of the Pindaric high-born and silent victor may have been fused into Nietzsche's ideal; certainly Bacchic freedom and ardour were to enter in. But on the whole it is remarkable how little he learned from the Greeks, no modesty or reverence, no joy in order and in loveliness, no sense for friendship, none for the sanctity of places and institutions. He repeated the paradoxes of some of their sophists, without remembering how their wise men had refuted them. For example, he gave a new name and a new prominence to the distinction between what he called the Dionysiac and the Apollonian elements in Greek genius. He saw how false was that whitewashed notion of the Greek mind which young ladies derived from sketching a plaster cast of the Apollo Belvidere. ${ }^{1} \mathrm{He}$ saw that a demonic force, as the generation of Goethe called it, underlay everything; what he did not see was that this demonic force was under control, which is the secret of the

1 I was about to say: How false was the notion of Winkelmann about the grandeur and repose of the Greek spirit. But Winkelmann, if his sense for the chained monsters in the Greek soul was inadequate, was at least in real sympathy with what had inspired Greek sculpture, love and knowledge of the human body in the life, made gentle by discipline and kept strong by training. For that reason Winkelmann seems hardly a German: his learning was deficient and his heart was humble. He did not patronise the ancients, he believed in them. 
whole matter. The point had been thoroughly elucidated by Plato, in the contrast he drew between inspiration and art. But Plato was rather ironical about inspiration, and had a high opinion of art; and Nietzsche, with his contrary instinct, rushes away without understanding the mind of the master or the truth of the situation. He thinks he alone has discovered the divinity of Dionysus and of the Muses, which Plato took as a matter of course but would not venerate superstitiously. Inspiration, like will, is a force without which reason can do nothing. Inspiration must be presupposed; but in itself it can do nothing good unless it is in harmony with reason, or is brought into harmony with it. This two-edged wisdom that makes impulse the stuff of life and reason its criterion, is, of course, lost on Nietzsche, and with it the whole marvel of Greek genius. There is nothing exceptional in being alive and impulsive; any savage can run wild and be frenzied and enact histrionic passions: the virtue of the Greeks lay in the exquisite firmness with which they banked their fires without extinguishing them, so that their life remained human (indeed, remained infra-human, like that of Nietzsche's superman) and yet became beautiful: they were severe and fond of maxims, on a basis of universal tolerance; they governed themselves rationally, with a careful freedom, while well aware 


\section{I42 EGOTISM IN GERMAN PHILOSOPHY}

that nature and their own bosoms were full of gods, all of whom must be reverenced.

After all, this defect in appreciation is inseparable from the transcendental pose. The ancients, like everything else, never seem to the egotist a reality co-ordinate with himself, from which he might still have something to learn. They are only so much " content" for his self-consciousness, so much matter for his thought to transcend. They can contain nothing for him but the part of his outgrown self which he deigns to identify with them. His mind must always envelop them and be the larger thing. No wonder that in this school learning is wasted for the purposes of moral education. Whoever has seen the learned egotist flies at his approach. History in his hands is a demonstration of his philosophy. Science is a quarry of proofs for his hobbies. If we do not agree with him we are not merely mistaken (every philosopher tells us that), but we are false to ourselves and ignorant of our ideal significance. His ego gives us our place in the world. He informs us of what we mean, whatever we may say; and he raises our opinions, as he might his food, to a higher unity in his own person. He is priest in every temple. $\mathrm{He}$ approaches a picture-gallery or a foreign religion in a dictatorial spirit, with his a priori categories ready on his lips; pedantry and vanity speak in his 
every gesture, and the lesson of nothing can reach his heart.

No, neither the philosophy inherited by Nietzsche nor his wayward imagination was fit to suggest to him a nobler race of men. On the contrary, they shut him off from comprehension of the best men that have existed. Like the utopias or ideals of many other satirists and minor philosophers, the superman is not a possibility, it is only a protest. Our society is outworn, but hard to renew; the emancipated individual needs to master himself. In what spirit or to what end he will do so, we do not know, and Nietzsche cannot tell us. $\mathrm{He}$ is the jester, to whom all incoherences are forgiven, because all indiscretions are allowed. His mind is undisciplined, and his tongue outrageous, but he is at bottom the friend of our conscience, and full of shrewd wit and tender wisps of intuition. Behind his "gay wisdom" and trivial rhymes lies a great anguish. His intellect is lost in a chaos. His heart denies itself the relief of tears and can vent itself only in forced laughter and mock hopes that gladden nobody, least of all himself. 


\section{CHAPTER XIV}

\section{HEATHENISM}

Schopenhauer somewhere observes that the word heathen, no longer in reputable use elsewhere, had found a last asylum in Oxford, the paradise of dead philosophies. Even Oxford, I believe, has now abandoned it; yet it is a good word. It conveys, as no other word can, the sense of vast multitudes tossing in darkness, harassed by demons of their own choice. No doubt it implies also a certain sanctimony in the superior person who uses it, as if he at least were not chattering in the general Babel. What justified Jews, Christians, and Moslems (as Mohammed in particular insisted) in feeling this superiority was the possession of a Book, a chart of life, as it were, in which the most important features of history and morals were mapped out for the guidance of teachable men. The heathen, on the contrary, were abandoned to their own devices, and even prided themselves on following only their spontaneous will, their habit, presumption, or caprice.

Most unprejudiced people would now agree that the value of those sacred histories and rules of life did not depend on their alleged miraculous origin, 
but rather on that solidity and perspicacity in their authors which enabled them to perceive the laws of sweet and profitable conduct in this world. It was not religion merely that was concerned, at least not that outlying, private, and almost negligible sphere to which we often apply this name; it was the whole fund of experience mankind had gathered by living; it was wisdom. Now, to record these lessons of experience, the Greeks and Romans also had their Books; their history, poetry, science, and civil law. So that while the theologically heathen may be those who have no Bible, the morally and essentially heathen are those who possess no authoritative wisdom, or reject the authority of what wisdom they have; the untaught or unteachable who disdain not only revelation but what revelation stood for among early peoples, namely, funded experience.

In this sense the Greeks were the least heathen of men. They were singularly docile to political experiment, to law, to methodical art, to the proved limitations and resources of mortal life. This life they found closely hedged about by sky, earth, and sea, by war, madness, and conscience with their indwelling deities, by oracles and local genii with their accustomed cults, by a pervasive fate, and the jealousy of invisible gods. Yet they saw that these divine forces were constant, and that they exercised 


\section{I46 EGOTISM IN GERMAN PHILOSOPHY}

their pressure and bounty with so much method that a prudent art and religion could be built up in their midst. All this was simply a poetic prologue to science and the arts; it largely passed into them, and would have passed into them altogether if the naturalistic genius of Greece had not been crossed in Socrates by a premature discouragement, and diverted into other channels.

Early Hebraism itself had hardly been so wise. It had regarded its tribal and moral interests as absolute, and the Creator as the champion and omnipotent agent of Israel. But this arrogance and inexperience were heathen. Soon the ascendency of Israel over nature and history was proclaimed to be conditional on their fidelity to the Law; and as the spirit of the nation under chastisement became more and more penitential, it was absorbed increasingly in the praise of wisdom. Salvation was to come only by repentance, by being born again with a will wholl transformed and broken; so that the later Jewish religion went almost as far as Platonism or Christianity in the direction opposite to heathenism.

This movement in the direction of an orthodox wisdom was regarded as a progress in those latter days of antiquity when it occurred, and it continued to be so regarded in Christendom until the rise of romanticism. The most radical reformers simply 
urged that the current orthodoxy, religious or scientific, was itself imperfectly orthodox, being corrupt, overloaded, too vague, or too narrow. As every actual orthodoxy is avowedly incomplete and partly ambiguous, a sympathetic reform of it is always in order. Yet very often the reformers are deceived. What really offends them may not be what is false in the received orthodoxy, but what though true is uncongenial to them. In that case heathenism, under the guise of a search for a purer wisdom, is working in their souls against wisdom of any sort. Such is the suspicion that Catholics would throw on Protestantism, naturalists on idealism, and conservatives generally on all revolutions.

But if ever heathenism needed to pose as constructive reform, it is now quite willing and able to throw off the mask. Desire for any orthodox wisdom at all may be repudiated; it may be set down to low vitality and failure of nerve. In various directions at once we see to-day an intense hatred and disbelief gathering head against the very notion of a cosmos to be discovered, or a stable human nature to be respected. Nature, we are told, is an artificial symbol employed by life; truth is a temporary convention; art is an expression of personality; war is better than peace, effort than achievement, and feeling than intelligence; change is deeper than 


\section{I48 EGOTISM IN GERMAN PHILOSOPHY}

form; will is above morality. Expressions of this kind are sometimes wanton and only half thought out; but they go very deep in the subjective direction. Behind them all is a sincere revulsion against the difficult and confused undertakings of reason; against science, institutions, and moral compulsions. They mark an honest retreat into immediate experience and animal faith. Man used to be called a rational animal, but his rationality is something eventual and ideal, whereas his animality is actual and profound. Heathenism, if we consider life at large, is the primal and universal religion.

It has never been my good fortune to see wild beasts in the jungle, but I have sometimes watched a wild bull in the ring, and I can imagine no more striking, simple, and heroic example of animal faith; especially when the bull is what is technically called noble, that is, when he follows the lure again and again with eternal singleness of thought, eternal courage, and no suspicion of a hidden agency that is mocking him. What the red rag is to this brave creature, their passions, inclinations, and chance notions are to the heathen. What they will they will; and they would deem it weakness and disloyalty to ask whether it is worth willing or whether it is attainable. The bull, magnificently sniffing the air, surveys the arena with the cool contempt and 
disbelief of the idealist, as if he said: "You seem, you are a seeming; I do not quarrel with you, I do not fear you. I am real, you are nothing." Then suddenly, when his eye is caught by some bright cloak displayed before him, his whole soul changes. His will awakes and he seems to say: "You are my destiny; I want you, I hate you, you shall be mine, you shall not stand in my path. I will gore you. I will disprove you. I will pass beyond you. I shall be, you shall not have been." Later, when sorely wounded and near his end, he grows blind to all these excitements. He smells the moist earth, and turns to the dungeon where an hour ago he was at peace. He remembers the herd, the pasture beyond, and he dreams: "I shall not die, for I love life. I shall be young again, young always, for I love youth. All this outcry is nought to me, this strange suffering is nought. I will go to the fields again, to graze, to roam, to love."

So exactly, with not one least concession to the unsuspected reality, the heathen soul stands bravely before a painted world, covets some bauble, and defies death. Heathenism is the religion of will, the faith which life has in itself because it is life, and in its aims because it is pursuing them.

In their tentative, many-sided, indomitable way, the Germans have been groping for four hundred 


\section{I50 EGOTISM IN GERMAN PHILOSOPHY}

years towards a restoration of their primitive heathenism. Germany under the long tutelage of Rome had been like a spirited and poetic child brought up by very old and very worldly foster-parents. For many years the elfin creature may drink in their gossip and their maxims with simple wonder; but at last he will begin to be restive under them, ask himself ominous questions, protest, suffer, and finally break into open rebellion. Naturally he will not find at first theories and precepts of his own to take the place of his whole education; he will do what he can with his traditions, revising, interpreting, and patching them with new ideas; and only if he has great earnestness and speculative power will he ever reach an unalloyed expression of his oppressed soul.

Now in Germany speculative power and earnestness existed in a high degree, not, of course, in most people, but in the best and most representative; and it was this élite that made the Reformation, and carried it on into historical criticism and transcendental philosophy, until in the nineteenth century, in Schopenhauer, Wagner, and Nietzsche, the last remnants of Christian education were discarded and the spontaneous heathen morality of the race reasserted itself in its purity. That this assertion was not consistent, that it was thrown into the language and images of some alien system, is not to be 
wondered at; but the Christianity of Parsifal, like the Buddhism of the denial of the will, is a pure piece of romanticism, an exotic setting for those vacillations and sinkings which absolute Will may very well be subject to in its absolute chaos.

The rebellion of the heathen soul is unmistakable in the Reformation, but it is not recognised in this simple form, because those who feel that it was justified do not dream that it was heathen, and those who see that it was heathen will not admit that it was justified. Externally, of course, it was an effort to recover the original essence of Christianity; but why should a free and absolute being care for that original essence when he has discovered it, unless his own mind demanded that very thing? And if his mind demanded it, what need has he to read that demand into an ancient revelation which, as a matter of fact, turned on quite other matters? It was simply the inertia of established prejudice that made people use tradition to correct tradition; until the whole substance of tradition, worn away by that internal friction, should be dissolved, and impulse and native genius should assert themselves unimpeded.

Judaism and Christianity, like Greek philosophy, were singly inspired by the pursuit of happiness, in whatever form it might be really attainable: now 


\section{I52 EGOTISM IN GERMAN PHILOSOPHY}

on earth if possible, or in the millennium, or in some abstracted and inward life, like that of the Stoics, or in the last resort, in a different life altogether beyond the grave. But heathenism ignores happiness, despises it, or thinks it impossible. The regimen and philosophy of Germany are inspired by this contempt for happiness, for one's own happiness as well as for other people's. Happiness seems to the German moralists something unheroic, an abdication before external things, a victory of the senses over the will. They think the pursuit of happiness low, materialistic, and selfish. They wish everybody to sacrifice or rather to forget happiness, and to do " deeds."

It is in the nature of things that those who are incapable of happiness should have no idea of it. Happiness is not for wild animals, who can only oscillate between apathy and passion. To be happy, even to conceive happiness, you must be reasonable or (if Nietzsche prefers the word) you must be tamed. You must have taken the measure of your powers, tasted the fruits of your passions and learned your place in the world and what things in it can really serve you. To be happy you must be wise. This happiness is sometimes found instinctively, and then the rudest fanatic can hardly fail to see how lovely it is; but sometimes it comes of having learned something by experience (which empirical people never 
do) and involves some chastening and renunciation; but it is not less sweet for having this touch of holiness about it, and the spirit of it is healthy and beneficent. The nature of happiness, therefore, dawns upon philosophers when their wisdom begins to report the lessons of experience: an a priori philosophy can have no inkling of it.

Happiness is the union of vitality with art, and in so far as vitality is a spiritual thing and not mere restlessness and vehemence, art increases vitality. It obviates friction, waste, and despair. Without art, vitality is painful and big with monsters. It is hurried easily into folly and crime; it ignores the external forces and interests which it touches. German philosophy does this theoretically, by dethroning the natural world and calling it an idea created by the ego for its own purposes; and it does this practically also by obeying the categorical imperative -no longer the fabled imperatives of Sinai or of Königsberg, but the inward and vital imperative which the bull obeys, when trusting absolutely in his own strength, rage, and courage, he follows a little red rag and his destiny this way and that way. 


\section{CHAPTER XV}

\section{GERMAN GENIUS}

IT is customary to judge religions and philosophies by their truth, which is seldom their strong point; yet the application of that unsympathetic criterion is not unjust, since they aspire to be true, maintain that they are so, and forbid any opposed view, no matter how obvious and inevitable, to be called true in their stead. But when religions and philosophies are dead, or when we are so removed from them by time or training that the question of their truth is not a living question for us, they do not on that account lose all their interest; then, in fact, for the first time they manifest their virtues to the unbeliever. He sees that they are expressions of human genius; that however false to their subject-matter they may be, like the conventions of art they are true to the eye and to the spirit that fashioned them. And as nothing in the world, not even the truth, is so interesting as human genius, these incredible or obsolete religions and philosophies become delightful to us. The sting is gone out of their errors, which no longer threaten to delude us, and they have acquired a beauty invisible to the eye of their authors, because 
of the very refraction which the truth suffered in that vital medium.

German philosophy is a work of genius. To be heathen is easy; to have an absolute will and a belief in chaos-or rather a blind battle with chance -is probably the lot of most animals; but to be condemned to be learned, industrious, moral, and Christian, and yet, through that veil of unavoidable phenomena and conventions, to pierce to absolute will and freedom, and to set them forth persuasively as the true reality, in spite of all the ordered appearances which do not cease to confront and to occupy us-that is a work of genius. It is a wonderful achievement, to have recovered atavistically the depths of the primitive soul, in the midst of its later sophistication. In this philosophy the ancestral ego, the soul perplexed and incredulous at being born into this world, returns to haunt us in broad daylight and to persuade us with its ghostly eloquence that not that ego but this world is the ghost.

The egotism which in German philosophy is justified by a theory in German genius is a form of experience. It turns everything it touches into a part of its own life, personal, spontaneous, sincere, original. It is young and self-sufficient; yet as a continual change of view is incompatible with art and learning, we see in Germany, even more than elsewhere, 


\section{I56 EGOTISM IN GERMAN PHILOSOPHY}

a division of labour between genius and tradition; nowhere are the types of the young rebel and the tireless pedant so common and so extreme.

The notion that something that moves and lives, as genius does, can at the same time be absolute has some interesting implications. Such a genius and all its works must be unstable. As it has no external sources and no external objects, as its own past can exercise no control over it (for that would be the most lifeless of tyrannies), it is a sort of shooting star, with no guarantees for the future. This, for the complete egotist, has no terrors. A tragic end and a multitude of enemies may seem good to the absolute hero and necessary to his perfect heroism. In the same way, to be without a subject-matter or an audience may seem good to the absolute poet, who sings to himself as he goes, exclusively for the benefit of that glorious and fleeting moment. Genius could not be purer than that: although perhaps it might be hard to prove that it was genius.

A kindred implication, which perhaps might be less welcome to the egotist himself, is that an absolute genius is formless, and that the absolute freedom with which it thinks it takes on now this form and now that, is not really freedom at all, but subjection to unknown and perhaps ironical forces. Absolute Will, of which a perfectly free genius is an expression, 
cannot say specifically what it craves, for essentially it should crave everything indiscriminately. In practice, however, it must seem to aim at this or that precise result. These specific aims are suggested to it by circumstances, foisted upon it in its replete innocence; for it is all expectation, all vague heartiness and zeal for it knows not what. The logic it proclaims at any time and calls eternal is but the fashionable rhetoric of that hour. Absolute Will is a great dupe on whom fortune forces card after card. Like Faust it is helpless before the most vulgar temptations. Why should it not fulfil itself now by the pursuit of magic, now by the seduction of a young girl, now by an archæological pose, now by a piratical or an engineering enterprise? True, there are limits to its gullibility; there are suggestions from which it recoils. The German ego, after swallowing Christianity whole, will in Luther stick at Indulgences. Faust sometimes turns on Mephistopheles, as the worm will turn: he says that he covets all experience, but in that he does himself a great injustice; there are experiences he scorns. After all this ego is not really absolute; it is specifically and pathetically human and directed upon a few natural ends. That is what saves it; for a mind can have no distinction and a soul no honour if its only maxim is to live on. It may take up with enthusiasm what- 


\section{I58 EGOTISM IN GERMAN PHILOSOPHY}

ever it takes up, but it will take up anything; and it may do mightily whatever it does, but it will not do it long.

Consider, in this respect, the pathetic history of the German people. It conquered the Roman empire and it became Roman, or wished to become so. It had had a mythology and a morality of its own (very like in principle to those it has since rediscovered), yet it accepted Christianity with the docility of a child. It began to feel, after some centuries, how alien to its genius this religion was, but it could find relief only in a fresh draught from the same foreign sources, or others more remote. To cease to be Roman it tried to become Hebraic and Greek. In studying these models, however, it came upon a new scent. What passed for revelation or for classical perfection was of human national growth, stratified like the rocks, and not divine or authoritative at all. If you only made hypotheses enough, you could prove how it all arose according to necessary laws, logical, psychological, historical, economical, and æsthetical. Above all, you could prove how nobody had understood anything properly before, and how the key to it all was in your single hand.

Yet the triumphs of theory alone soon seemed unsatisfying. Wine, science, and song once seemed to make Germany happy, but if a prince imposed 
military discipline, might not that be an even better thing? For a time wistfulness, longing, and the feeling of Titanic loneliness and of a world to be evoked and snuffed out like a dream, seemed to fill the cup of intense living, and the greatest and happiest of Germans could cry-

\section{Nur wer die Sehnsucht kennt weiss, was ich leide, allein und abgetrennt von aller Freude.}

But presently true intensity of life appeared to lie rather in being a victorious general, or an ironmaster, or a commercial traveller, or a reveller in the Friedrichstrasse, or a spy and conspirator anywhere in the world.

All these turbid and nondescript ambitions are in a sense artificial; the Germans accept them now as a thousand years ago they accepted Christianity, because such things are suddenly thrust upon them. By nature they are simple, honest, kindly, easily pleased. There is no latent irony or disbelief in their souls. The pleasures of sense, plain and copious, they enjoy hugely, long labour does not exasperate them, science fills them with satisfaction, music entrances them. There ought to be no happier or more innocent nation in this world. Unfortunately their very goodness and simplicity render them helpless; they are what they are dragooned to be. There is no social or intellectual disease to which, in spots, 
they do not succumb, as to an epidemic: their philosophy itself is an example of this. They have the defects of the newly prosperous; they are far too proud of their possessions, esteeming them for being theirs, without knowing whether they are good of their kind. Culture is a thing seldom mentioned by those who have it. The real strength of the Germans lies not in those external achievements of which at this moment they make so much-for they may outgrow this new materialism of theirs-it lies rather in what they have always prized, their Gemüth and their music.

Perhaps these two things have a common root. Emotion is inarticulate, yet there is a mighty movement in it, and a great complexity of transitions and shades. This intrinsic movement of the feelings is ordinarily little noticed because people are too wide awake, or too imaginative. Everything is a fact or a picture to them, and their emotions seem to them little but obvious qualities of things. They roundly call things beautiful, painful, holy, or ridiculous; they do not speak of their Gemüth, although, of course, it is by virtue of their emotions that they pass such judgments. But when the occasions of our emotions, the objects that call them forth, are not so instantly focussed, when we know better what we feel than why we feel it, then we seem to have a richer and more massive sensibility. Our feelings 
absorb our attention because they remain a thing apart: they seem to us wonderfully deep because we do not ground them in things external.

Now music is a means of giving form to our inner feelings without attaching them to events or objects in the world. Music is articulate, but articulate in a language which avoids, or at least veils the articulation of the world we live in; it is, therefore, the chosen art of a mind to whom the world is still foreign. If this seems in one way an incapacity, it is also a privilege. Not to be at home in the world, to prize it chiefly for echoes which it may have in the soul, to have a soul that can give forth echoes, or that can generate internal dramas of sound out of its own resources-may this not be a more enviable endowment than that of a mind all surface, a sensitive plate only able to photograph this not too beautiful earth? In any case, for better or for worse, inward sensibility, unabsorbed in worldly affairs, exists in some people; a life, as it were, still in the womb and not yet in contact with the air. But let these inspired musicians, masters in their own infinite realms, beware of the touch of matter. Let them not compose a system of the universe out of their Gemüth, as they might a symphony. Let them not raise their bâton in the face of the stars or of the nations, and think to lead them like an orchestra. 


\section{CHAPTER XVI}

EGOTISM IN PRACTICE

Theories in their own ethereal essence can have no influence on events. But the men who conceive and adopt a theory form, in doing so, certain habits of discrimination and of reaction to things. In fact, they have conceived and adopted their theory because their habits of apprehension and action suggested it to them, or could be brought to suggest it: the explicit theory is a symbol and omen of their practical attitude, of their way, as the phrase has it, of grasping the situation.

All philosophies have the common property of being speculative, and, therefore, their immediate influence on those who hold them is in many ways alike, however opposed the theories may be to one another: they all make people theoretical. In this sense any philosophy, if warmly embraced, has a moralising force, because, even if it belittles morality, it absorbs the mind in intellectual contemplation, accustoms it to wide and reasoned comparisons, and makes the sorry escapades of human nature from convention seem even more ignominious than its ruling prejudices.

The particular theory of egotism arises from an 162 
exorbitant interest in ourselves, in the medium of thought and action rather than in its objects. It is not necessarily incorrect, because the self is actual and indispensable; but the insistence on it is a little abnormal, because the self, like consciousness, ought to be diaphanous. Egotism in philosophy is, therefore, a pretty sure symptom of excessive pedantry and inordinate self-assertion.

In the lofty theory of egotism life is represented as a sort of game of patience, in which the rules, the cards, the table, and the empty time on our hands, all are mere images created by the fancy, as in a dream. The sense of being occupied, though one really has nothing to do, will then be the secret of the whole affair, and the sole good to be attained by living. Of course this fantastic theory is put forward only on great occasions, when an extreme profundity is in place; but like other esoteric doctrines it expresses very well the spirit in which those people live habitually who would appeal to it in the last resort. Obviously such an egotist should in consistency be a man of principle. He would feel it to be derogatory to his dignity, and contrary to his settled purpose, to cheat at the game he has instituted. That luck should sometimes go against him is preordained by himself; otherwise the game would have no zest, and to be interested, to be pressed, 


\section{I64 EGOTISM IN GERMAN PHILOSOPHY}

even to be annoyed seems the highest good to him in his great tedium. He will, therefore, be assiduous, patient, and law-abtling; and the idea of ever abandoning his chosen game for anything less forced and less arbitrary will seem to him disloyalty to himself, and a great wickedness.

Indeed, nothing beside his own purpose will have any value in his eyes, or even any existence. He will therefore inevitably act without consideration for others, without courtesy, without understanding. When he chooses to observe anything external-and he is studious-his very attentions will be an insult; for he will assume that his idea of that external thing is the reality of it, and that other people can have only such rights and only such a character as he is willing to assign to them. It follows from his egotistical principles that in judging others he should be officious and rude, learned and mistaken.

What the egotist calls his will and his ideals are, taken together, simply his passions; but the passions of the egotist are turned into a system and go unrebuked. A man who lowers his precepts to the level of his will may the more easily raise his practice to the level of his precepts. He endows his life with a certain coherence, momentum, and integrity, just because he has suppressed all vain aspiration and all useless shame. He does not call himself a sinner; 
he would be at a loss for a reason to think himself one; for really his standard of virtue expresses nothing but his prevalent will. Is it not intelligible that such a morality should be more efficacious, more unifying, heavier, and more convinced than one which begins by condemning our natural passions and the habitual course of human life?

In fact, egotism in practice is a solemn and arduous business; there is nothing malicious about it and nothing gay. There is rather a stolid surprise that such honest sentiments and so much enterprise should not meet everywhere with applause. If other people are put thereby at a disadvantage, why should they not learn their lesson and adopt in their turn the methods of the superman? If they are touched by the vanity and the charm of existence and neglect the intense pursuit of their absolute will, why do they complain if they are jostled and beaten? Only he deserves life and freedom, said Goethe, who is forced daily to win them afresh.

If the egotist suffers passion to speak in his philosophy, it is perhaps because he has so little passion. Men of frank passions quickly see the folly of them; but the passions of the egotist are muffled, dull, like the miserly passions of old men; they are diffused into sensuality and sentiment, or hardened into maxims. Egotistical lovers can hold hands for hours 


\section{I66 EGOTISM IN GERMAN PHILOSOPHY}

and chastely kiss each other for years; such tokens of affection help to keep them in love and at the same time are a sop to more troublesome impulses. Sentimentality and gush mark the absence of passion: the blood has been diluted to lymph. Hence the egotist can the more easily mistake his passions for duties, and his cupidities for ideals. His devotion to these ideals is pure and enthusiastic; but in serving them he fattens steadily, as punctual at his work as at his meals, as dutifully moved by the approved music as by the official patriotism, vicious when it seems manly to be vicious, brutal when it seems politic to be brutal; he feels he is impeccable, and he must die in his sins. Nothing can ruffle the autonomous conscience of this kind of idealist, whose nature may be gross, but whose life is busy and conventional, and who loudly congratulates himself daily on all he knows and does.

Turn the circumstances about as you like, the egotist finds only one ultimate reason for everything. It is not a reason; it is absolute will. Suppose we asked the ego, in the Fichtean system, why it posited a material world to be its implacable enemy and rebellious toy, and why without necessity it raised this infinity of trouble for itself and for the unhappy world which it created by its fiat. It could only reply: "Because such is the categorical imperative 
within me; because so I will, so I must, and so my absolute duty and its logic require. If the consequences are tragic-and in the end I know they must be tragic-that only proves the sublime unselfishness of my egotism, the purity of my sacred folly, the ideality of my groundless will. All reasons, all justifications which might appeal to me must be posterior to my will; my will itself can have no justification and no reason."

Let us admire the sincerity of this searching confession. Virtue itself, if it relied on self-consciousness for its philosophy, could not justify itself on other grounds. If the difference between virtue and vice is hereby obliterated, that only proves that the difference is not founded on self-consciousness but on the circumstances and powers under which we live. What self-consciousness can disclose is not the basis of anything. All will.is the expression of some animal body, frail and mortal, but teachable and rich in resource. The environment in which this will finds itself controls and rewards its various movements, and establishes within it the difference between virtue and vice, wisdom and folly.

The whole transcendental philosophy, if made ultimate, is false, and nothing but a private perspective. The will is absolute neither in the individual nor in humanity. Nature is not a product of 


\section{I68 EGOTISM IN GERMAN PHILOSOPHY}

the mind, but on the contrary there is an external world, ages prior to any idea of it, which the mind recognises and feeds upon. There is a steady human nature within us, which our moods and passions may wrong but cannot annul. There is no categorical imperative but only the operation of instincts and interests more or less subject to discipline and mutual adjustment. Our whole life is a compromise, an incipient loose harmony between the passions of the soul and the forces of nature, forces which likewise generate and protect the souls of other creatures, endowing them with powers of expression and selfassertion comparable with our own, and with aims no less sweet and worthy in their own eyes; so that the quick and honest mind cannot but practise courtesy in the universe, exercising its will without vehemence or forced assurance, judging with serenity, and in everything discarding the word absolute as the most false and the most odious of words. As Montaigne observes, " $\mathrm{He}$ who sets before him, as in a picture, this vast image of our mother Nature in her entire majesty; who reads in her aspect such universal and continual variety; who discerns himself therein, and not himself only but a whole kingdom, to be but a most delicate dot-he alone esteems things according to the just measure of their greatness." 


\section{INDEX}

Alexander the Great, a model for German idealists, 80, $8 \mathrm{I}$ Aristotle, I 20, 124

Belief in God, disproved pragmatically, I 34

Bull-psychology, I48, 153

Burckhardt, 47

Byron, 48, 49

Cæsar Borgia, a superman, I 38

Calvinism, in Kant, 57; in Fichte, 25, 77; in Hegel, I I I

Categorical imperative, its origin, 56; its prerogatives, 62; its dangers, 63

Chancellor, the German, his chivalrous after - thought about Belgium, 50

Christianity, foreign to Germany, II ; undermined by German philosophy, 104, 10 5 ; patronised by Goethe, 46; abandoned by romantic individualists, 107; denounced by Nietzsche, I 30-I 32; has one element in common with egotism, I06

Classicism, romantic in Goethe, 46; missed by Nietzsche, I 39-I 42; when truly vital, 48

Conquest, a sublime duty, 80, $8 \mathrm{I}$ Contraries, alleged to be inseparable, 89,90

Criticism, historical, has a transcendental basis, 29

Critique of Pure Reason, its agnosticism, I4; its sophistical foundation, 20
Dürer, 27

Egotism, defined, 6; distinguished from selfishness, 9597, I00-102, II8; based on error, 167 ; implicit in the Kantian imperative and postulates, 62-64; implies integrity, force, self-complacency, 163-166; is odious in pedants, 142

Emerson, 24, 49; quoted, I I9 England, judged by Fichte, 76

Evil, justified, I 23, I 32-I 34

Faith, German conception of it, I3, 27; corroborated only by itself, 3 I, 68

Faust, typical egotist, I 3, I 4; prefigures the evolution of Germany, 50, 51, I 57; improves on Saint John, 52

Fichte, $65-83$

Gemüth, why self-conscious, I60 German ethics, its faults, 103

German language, its merits, 75

German nation, its purity, 75 ; its mission, 78,79 ; in what sense the chosen people, 73 , 74; necessary to the continued existence of God, 68; and of history, 79 ; its fortunes, I 58-160

German philosophy, not all philosophy in Germany, II ; primitive, 27; subjective, I2; in what senses idealistic, 15; in what sense not so, 16 ; ambiguous, 17,18 ; a revela- 


\section{I70 EGOTISM IN GERMAN PHILOSOPHY}

tion, 22; must continually be proved afresh, 26; is a work of genius, I 55

Gobineau, 77

Goethe, 43-53; quoted, I59, I65

Good and evil above right and wrong, I 24

Gospel, amended by Faust, 52; glossed by Hegelians, 105

Happiness, not for the egotist, 14, I 5; he despises it, I 52 ; not abstract nor absolute, I IO, III; attainable, I I 8; its nature, 152,153

Heathenism, use of the word, I44; contrast with paganism, 145. I46; its modern form, I 47,148

Hegel, 84-98

Human nature, II 7, I 18

Idealism, meanings of the word, 15. I6; fosters practical materialism, 5, 69-72, 78, 8I, 82 ; should be imposed on the young, 80; its mystical issue, $38-40$

Ideals, when captious, when solid, 137

Infinity, evaded by Hegel, 88,89 ; recognised again by Schopenhauer, 108, 109

Kant, 54-64; 25, 34, 35, 42

Knowledge, assumed to be impossible, I5; abuse of the term, 39, 60

Leibniz, anticipates transcendentalism, 33; his insidious theology, 104

Lessing, on truth, 129

Locke, sets the ball rolling, 32

Luther, I35, I 57
Max Stirner, 99-103; quoted, 73 Montaigne, quoted, 168

Music, I6, 161

Musset, 49

Mysticism, in knowledge, $38-40$; in morals, 123

Nietzsche, I I 4-I 43

Optimism, egotistical, 25, I I I, I 14, I 6 , I I 8 , I I 9

Passion, not naturally egotistical, IOI; may become so, 95,98 ; dull in egotists, 165,166

Paulsen, 42

Perception, terminates in things not in ideas, I 9

Pessimism, inherits disregard of intrinsic values, I09; reacts against optimism, 25, I I I ; is arbitrary, I 6

Pier Gynt, typical egotist, I 3, I4 Plato, his idealism contrasted with the German, I6; his oppressive politics, $8 \mathrm{I}$; on inspiration, $14 \mathrm{I}$

Postulates of practical reason, equivocal, 58-64

Power, divers meanings of the word, I 25-I 27

Preservation, no law of nature, I 5

Progress, when illusory, 17 ; when real, i 2

Protestantism, 2I-3I, I 5 I

Religion in German philosophy, $7,13,75,76,82,83$

Rome and German genius, 150

Schopenhauer, I08-I 22

Selfishness, distinguished from egotism, 95, 97, 100-102, I I 8 


\section{INDEX}

Society, its alleged consciousness, 17, 18; a "spook," 99

Socrates, 146

Spinoza, religious feeling transferred to nature, 24 ; his mysticism in ethics, 123

Spirit, its meanings, 37 ; its mystic unity, 38

State, the absolute, an idol, 9698

Substance, egotistical use of the term, 17,92

Superman, I 36-1 43

Tender minds, how attracted to German philosophy, 24

Transcendentalism, 32-42

Truth, a figment of the will, 28; made in Germany, 88; less valuable than illusion, I4, I 28-I 30; not the strong point of philosophies, 154

Understanding, hostility of Hegel to the, 90,9 I

Wagner, 1 36, 150

War, a boon, 96; how it should be started, 79; is to rage for two hundred years, II 5

Wilhelm Meister, 44

Will, used metaphorically, 36, I 4 ; should be disinterested, 67: may be fulfilled in defeat, 66,$67 ;$ is unstable and indeterminate, $156-158$; may be denied, I I 9,120

Winkelmann, 140 , note 


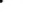





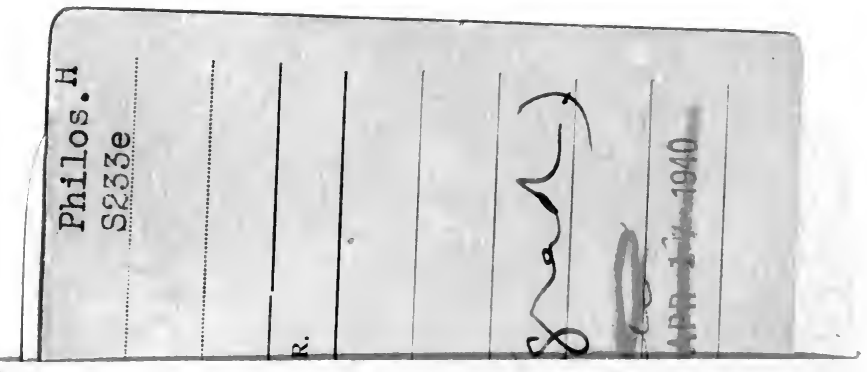


